\title{
Reflux stratabound dolostone and hydrothermal volcanism-associated dolostone: a two-stage dolomitization model (Jurassic, Lebanon)
}

\author{
FADI H. NADER ${ }^{1 *}$, RUDY SWENNEN* and ROB ELLAM† \\ *Afd. Fysico-chemische Geologie, Katholieke Universiteit Leuven, Celestijnenlaan 200C, \\ B-3001 Heverlee, Belgium \\ $\dagger$ †cottish Universities Environmental Research Centre, Rankine Avenue, East Kilbride G75 0QF, UK
}

\begin{abstract}
The Kesrouane Formation, which is characterized by pervasive dolomitization, has a stratigraphic thickness that exceeds $1000 \mathrm{~m}$. It is part of a broad carbonate platform deposited in the Levant region and represents $60 \%$ of the Lebanese Jurassic rocks. Two genetically distinct dolostones are recognized within this unit: (1) fine-to-medium crystalline non-planar grey dolostone; and (2) coarse-crystalline planar beige dolostone. The former is stratabound and of Early Jurassic age $\left({ }^{87} \mathrm{Sr} /{ }^{86} \mathrm{Sr}=0 \cdot 707455\right)$. This dolostone locally exhibits pseudomorphs of evaporite nodules, pointing towards seepage-reflux dolomitization by hypersaline- to marine-related fluids. Exposures of the coarse-crystalline dolostone are associated with regional pre-Cretaceous faults, along which Late Jurassic volcanics also occur. Sedimentological and diagenetic considerations coupled with microthermometry support a hydrothermal origin for this dolostone, with $\mathrm{T}_{\mathrm{H}}$ values of primary inclusions between 50 and $80{ }^{\circ} \mathrm{C}$. The related dolomitizing fluids are mesosaline (3.5-12.0 eq. $\mathrm{wt} \% \mathrm{NaCl}$ ), and are believed to result from the mixing of evaporative brines and sea water. Dolomitization is thus believed to have occurred in two stages, whereby fluids invaded the host rocks first by seepage-reflux, explaining the resulting Early Jurassic stratabound dolostone, and later through fracture flow along the faults associated with the Late Jurassic volcanism, explaining the coarse-crystalline hydrothemal dolostone.
\end{abstract}

Keywords Dolomitization, isotopes, Lebanon, saddle dolomite.

\section{INTRODUCTION}

Various dolomitization models have been proposed to date, covering many diagenetic environments and involving fluids with a wide range of chemical composition [e.g. reflux, sabkha, mixing zone (Dorag, Kohout), burial, hydrothermal, sea water, microbial; Adams \& Rhodes, 1960; Butler, 1969; Badiozamani, 1973; Folk \& Land, 1975; Mattes \& Mountjoy, 1980; Saller, 1984; Simms, 1984; Ward \& Halley, 1985; Humphrey, 1988; Machel \& Burton, 1994; Muchez \& Viaene, 1994;

${ }^{1}$ Present address: Department of Geology, American University of Beirut, PO Box 11-0236/26 - Beirut, Lebanon (E-mail: fadi.nader@aub.edu.lb).

(C) 2004 International Association of Sedimentologists
Vasconcelos \& McKenzie, 1997; Wright, 1997]. Yet, the enigma of dolomite is far from being universally solved, as at least four major questions remain subject to debate. They relate to (1) kinetics, (2) thermodynamics, (3) geometry (dimensions) and related mass balance, and (4) neomorphism (recrystallization). The kinetic problem, for example, is summarized by the rare crystallization of dolomite in today's marine settings, even though sea water is known to be supersaturated with dolomite (Hardie, 1987). No adequate thermodynamic control for the process of dolomitization has been established (dolomites are difficult to synthesize in the laboratory at temperatures lower than $100{ }^{\circ} \mathrm{C}$; Carpenter, 1980). With respect to geometry (dimension), 
there are major difficulties in explaining pervasive (thick and widespread) dolostone stocks randomly present throughout the geological record. Here, mass balance calculations (Land, 1980) often prove a dead-end for many models, failing to explain the regional dimension of dolomitized bodies. Dolomite recrystallization, as a neomorphic response to changes in the ambient physico-chemical conditions and time (Hardie, 1987; Nielsen et al., 1994), is often invoked to explain the loss of the original geochemical genetic information as well as what was left from the original carbonate rock texture preserved after initial dolomitization. The hydrogeological parameters and the time factor have to be added to complete the list (Machel, 1999; Melim \& Scholle, 2002). As dolomitization is mainly a process of replacement (dissolution precipitation), significant fluid flow is generally considered to be important. This is controlled by the permeability of the host rock, the quantity and chemical signature of dolomitizing fluids and the hydraulic gradient. In addition, time, during which all the variables have to be tuned positively for dolomitization, remains an essential and critical factor.

Broad and thick dolostone facies characterize the Triassic to Early Jurassic strata in the Levant region (Fig. 1; Lebanon, Syria, Jordan and Israel) as well as the eastern and central Mediterranean region (e.g. Soussi \& M'Rabet, 1994). These dolostones (average thickness exceeding $1000 \mathrm{~m}$ ) also incorporate interlayers of evaporites and shallow-marine limestones. Several models have been proposed to explain such dolostone occurrences in Israel. Magaritz (1975) favoured hydrothermal dolomitization and precluded the influence of meteoric and/or magmatic fluids, based on the observed $\delta^{13} \mathrm{C}$ values of the dolostones. Goldberg \& Bogoch (1978) suggested a

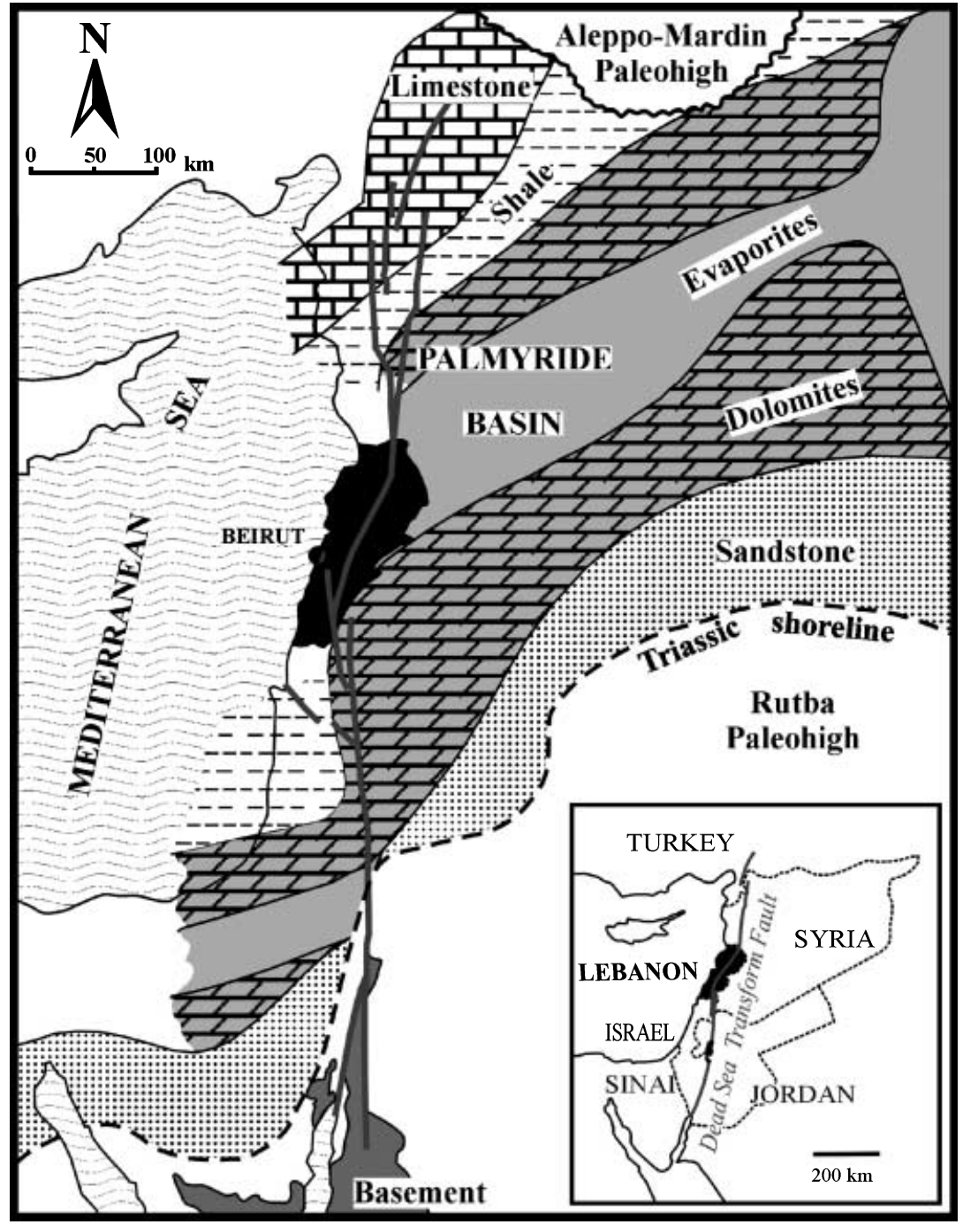

Fig. 1. Simplified Late Triassic facies map covering the Levant region (Renouard, 1967). The Early Jurassic facies replicated the previous Late Triassic ones (see text for details). 
two-stage dolomitization process, with an incipient stage affecting pelmicrite muds and occurring before lithification in the original marine realm. The second stage is characterized by the obliteration of the pelletal textures and the growth of the dolomite cement rims, in fluids reflecting different physico-chemical conditions. However, Buchbinder (1981) argued that dolomitization was post-depositional in relation to subsurface circulation of fluids either in the sea water-freshwater mixing zone or by warm subsurface brines. Buchbinder et al. (1984) discussed a karstic relationship for the dolomitization of Jurassic rocks from the coastal plain of Israel, based on stable isotopes - with the dolomitizing fluids made up of mixing two or more distinct fluids. Almost no substantial diagenetic data on dolostones of similar ages from Lebanon, Syria and Jordan are available. However, these rocks include hydrocarbon source rocks and also constitute potential economical reservoirs. Recently, Nader \& Swennen (2004) assessed the petroleum prospects of Lebanon disclosing sedimentological and diagenetic data about Early Jurassic carbonates.

Taking into account the major problems of the dolomitization process (as discussed above) and the perspective of the Levantine dolostones, this paper discusses two genetically distinct (but intermixed) dolostones: (1) stratabound fine crystalline dolostone, interpreted as reflux in origin; and (2) coarse-crystalline volcanism-associated dolostone, interpreted as hydrothermal. The authors, through this contribution, would especially like to stress the significance of field observation integrated with the many available techniques when dealing with dolostones. In addition, this paper invokes dolomitization by means of two distinct mechanisms (i.e. reflux and hydrothermal). Comparatively, many dolostone bodies that are exposed today could be the result of several rather than a single mechanism of dolomitization.

\section{REGIONAL SETTING AND GEOLOGICAL HISTORY}

The exposed Lebanese sedimentary sequence is made up predominantly of marine carbonate platform rocks ranging in age from Early Jurassic to recent, with a total stratigraphic thickness in the order of $5800 \mathrm{~m}$ (Dubertret, 1955; Beydoun, 1977a). Older sedimentary rocks (Palaeozoic to Early Jurassic) are believed to have a thickness ranging between 2800 and $3300 \mathrm{~m}$, based on palaeogeographic considerations and facies correlation (Beydoun, 1977a, b). The Palmyride basin (Fig. 1) is an intraplate trough trending almost NNE-SSW, part of which extends from the vicinities of the Euphrates River (NE Syria) to the Mediterranean Sea (offshore north Lebanon). It is bound to the south and north by the Rutbah and Aleppo-Mardin palaeohighs respectively. The genesis of the Palmyride basin is ascribed to the Late Permian (Lovelock, 1984) and is believed to cover a wider area from NE Egypt, through Israel, Lebanon and Syria, to NW Iraq (Wood, 2001). Continuous gentle subsidence prevailed during the deposition of widespread, mostly shallowmarine, Triassic and Jurassic sequences within the basin. Stratigraphic correlation shows that supposed Triassic, Jurassic and Cretaceous sequences thicken towards the present Mediterranean coastline (Lebanon and Israel; Wetzel, 1974; Beydoun, 1981; Mouty, 2000).

The Early Jurassic (Liassic) rocks have similar lithological characteristics to the underlying Triassic rocks, suggesting the continuation of the same depositional regime (e.g. Benjamini et al., 1993). In Israel, these strata mainly consist of cyclical deposition of sub- and supratidal carbonates, evaporites and continental clastics (Benjamini et al., 1993; Buchbinder \& Le Roux, 1993). The significance of the clastic components diminishes in Lebanon and Syria (away from the Triassic-Early Jurassic shoreline). Continuous marine settings prevailed in Lebanon without interruptions until the end of the Jurassic, when major tectonic movements started (Dubertret, 1955; Renouard, 1955). These movements were associated with volcanism leading to a local orogenic crisis mainly affecting the Jurassic platform in northern Lebanon. Subaerial and even prolonged continental conditions prevailed in the Kimmeridgian times. This can be viewed as a local reverse folding orogenesis within the Palmyride basin (Wood, 2001). The sea occasionally returned in the Late Jurassic and the Aptian, but the major transgression took place in the Cenomanian (the corresponding rock unit has an average thickness of $600 \mathrm{~m}$ in Lebanon). Although shallow-marine conditions returned with the advent of the Turonian, sedimentation in marine settings predominated until the Middle Eocene. A strong tectonic crisis, associated with the second phase of the Syrian Arc deformation, occurred in the Palaeogene (Walley, 1998), culminating in the final uplift of Mount Lebanon and resulting in the present regional structural and physiographic patterns. Volcanic activity 
resumed intermittently in the Miocene and throughout the Quaternary (Mouty et al., 1992), while the opening of the Red Sea evolved and the Dead Sea Transform Fault system originated. This short account on the geological history of the study area, and the Levant region (eastern Mediterranean), fits well into the general palaeogeography of the Tethys realm, which has recently been the subject of an international research project entitled 'Programme Peri-Tethys (PTP)' (e.g. Dercourt et al., 1993; Crasquin-Soleau \& Barrier, 1998, 2000; Ziegler et al., 2001).

\section{STUDY AREA}

The study area covers the Jurassic outcrop of central-northern Lebanon, which extends NNE-SSW from the vicinities of the capital city
Beirut (central Lebanon) to the Qadisha valley (northern Lebanon) with an approximate distance of $70 \mathrm{~km}$ (Fig. 2). In general, the Jurassic strata encountered form a tabular, gently dipping westward, monoclinal structure constituting the core of Mount Lebanon. Deep east-west canyons (e.g. Nahr Ibrahim) cross-cut this platform and provide relatively good accessibility for most of the Jurassic strata. The studied samples come from two key sections within the Kesrouane Formation: (1) Daraya tunnel in Jeita; and (2) Nahr Ibrahim valley (Fig. 2). The first is a vertical section corresponding to $200 \mathrm{~m}$ of dolostone and limestone strata exposed in a tunnel dug in the middle part of the formation. The second runs along an east-west valley across the western flank of Mount Lebanon, exposing the Jurassic sequence almost completely.

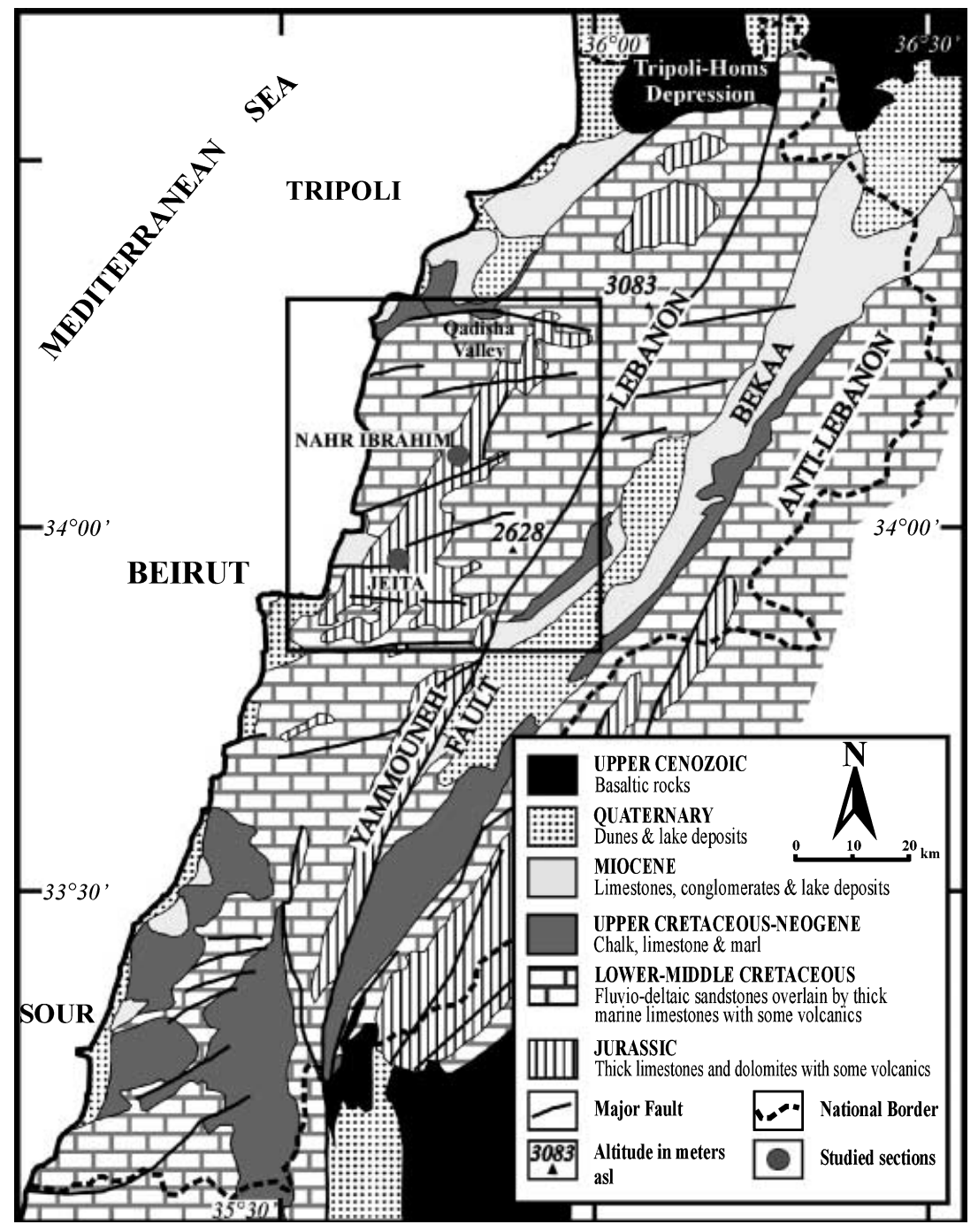

Fig. 2. Simplified geological map of Lebanon showing the extension of the study area and the two main sections (Jeita and Nahr Ibrahim) discussed in the present paper (after Dubertret, 1955). 


\section{METHODS}

Two hundred samples were subjected to petrographic observations including conventional and cathodoluminescence microscopy (CL; Technosyn Cold Cathodoluminescence model 8200, mark II; operation conditions were $16-20 \mathrm{kV}$ gun potential, $350-600 \mu \mathrm{A}$ beam current, 0.05 Torr vacuum and $5 \mathrm{~mm}$ beam width). Subsequently, various diagenetic phases were microsampled to measure their carbon and oxygen stable isotopic composition. Stable isotope analyses were done at the University of Erlangen, Germany (Institute of Geology and Mineralogy; Dr M. Joachimsky). The carbonate powders were reacted with $>100 \%$ phosphoric acid (density $>1.9$; Wachter \& Hayes, 1985) at $75^{\circ} \mathrm{C}$ in an online carbonate preparation line (Carbo-Kiel single sample acid bath) connected to a Finnigan Mat 252 mass spectrometer. All values are reported in per mil relative to Vienna Pee Dee Belemnite (V-PDB) by assigning a $\delta^{13} \mathrm{C}$ value of $+1.95 \%$ o and a $\delta^{18} \mathrm{O}$ value of $-2 \cdot 20 \%$ to NBS19. Oxygen isotopic compositions of dolomites were corrected using the fractionation factors given by Rosenbaum \& Sheppard (1986). Reproducibility based on replicate analysis of laboratory standards is better than $\pm 0 \cdot 02 \%$ for $\delta^{13} \mathrm{C}$ and $\pm 0.03 \%$ o for $\delta^{18} \mathrm{O}$.

Pieces of representative dolostone samples were crushed and powdered before mineralogical analysis by X-ray diffraction (XRD) using a Phillips PW1130 unit with fixed sample holder and proportional gas-filled counter. Co- $\mathrm{K} \alpha$ radiation (30 kV, $20 \mathrm{~mA})$ was used; halite and silicon were chosen as internal standards. Dolomite non-stoichiometry (mole $(\mathrm{M}) \% \mathrm{CaCO}_{3}$ ) was calculated using the relationship between calcium content and $d_{[104]}$ spacing (Goldsmith \& Graf, 1958) and applying the equation of Lumsden (1979) to the measured $d_{[104]}$ spacing. Dolomite ordering was assessed by calculating the FWHM (full width of half maximum intensity) of the dolomite peaks on X-ray diffractograms. Most of the analysed and interpreted dolostones are homogeneous (heterogeneous dolostones exhibit multiple peaks and/or shoulders; cf. Jones et al., 2001). Sr concentrations in dolostones and limestones were analysed by flame atomic absorption spectrometry (AAS). Powdered samples ( $1 \mathrm{~g}$ of each) were leached in $40 \mathrm{~mL}$ of $(1 \mathrm{M}) \mathrm{HCl}$ and left on hot plates until evaporation. The residues were dissolved for a second time in $20 \mathrm{~mL}$ of $(1 \mathrm{M}) \mathrm{HCl}$. After filtration and dilution, Sr was analysed. Analytical precision was generally better than $10 \%$ at the
95\% confidence level, and the detection limit was 1 p.p.m.

Sr isotope analyses were carried out at the Scottish Universities Environmental Research Centre. Carbonate samples were leached in $1 \mathrm{M}$ ammonium acetate before acid digestion. Calcite was digested in $1 \mathrm{M}$ acetic acid, and dolomite in $6 \mathrm{M} \mathrm{HCl}$. Sr was separated in $2.5 \mathrm{M} \mathrm{HCl}$ using Bio-Rad AG50W X8200-400 mesh cation exchange resin. Total procedure blank for $\mathrm{Sr}$ samples prepared using this method is $<200 \mathrm{pg}$. In preparation for mass spectrometry, Sr samples were loaded onto single Ta filaments with $1 \mathrm{~N}$ phosphoric acid. Sr samples were analysed on a VG Sector 54-30 multiple collector mass spectrometer. A ${ }^{88} \mathrm{Sr}$ intensity of $1 \mathrm{~V}(1 \times$ $\left.10^{-11} \mathrm{~A}\right) \pm 10 \%$ was maintained, and the ${ }^{87} \mathrm{Sr} /{ }^{86} \mathrm{Sr}$ ratio was corrected for mass fractionation using ${ }^{86} \mathrm{Sr} /{ }^{88} \mathrm{Sr}=0 \cdot 1194$ and an exponential law. The VG Sector 54-30 mass spectrometer was operated in the peak-jumping mode with data collected as 15 blocks of 10 ratios. For this instrument, NIST SRM987 gave $0 \cdot 710260 \pm 11(1 \mathrm{SD}, n=17)$ during the course of this study.

Microthermometry was performed on seven double-polished sections using a Linkam heating cooling stage. About 100 inclusions were observed, and 92 measurements of homogenization temperature $\left(\mathrm{T}_{\mathrm{H}}\right)$ were achieved. The inclusion size and the transparency of the host dolomite did not allow the measurement of the temperature of first melt $\left(\mathrm{T}_{\mathrm{FM}}\right)$ in all observed sections, whereas 20 measurements of the temperature of final melt $\left(\mathrm{T}_{\mathrm{M}}\right)$ were achieved. Measurement accuracy is in the order of $1{ }^{\circ} \mathrm{C}$ for $\mathrm{T}_{\mathrm{H}}$ values and $0 \cdot 2{ }^{\circ} \mathrm{C}$ for $\mathrm{T}_{\mathrm{M}}$ values.

\section{FIELD OBSERVATIONS}

The Kesrouane Formation is traditionally referred to as a thick monotonous sequence of carbonate rocks, where brownish dolostone and grey micritic limestone prevail (Dubertret, 1955). In the field, these rocks form a bluish mass, deeply and extensively karstified. They represent more than $60 \%$ of the Jurassic carbonates in Lebanon and stretch in age from Early to Late Jurassic (Fig. 3). The lower part of the formation is characterized by shallow to very shallow-marine depositional settings (e.g. dominance of bioclastic mudstone to wackestone with intercalations of stromatolites and oncolites; Fig. 4A and B) as well as local intertidal to subaerial exposures (fossilized roots; Fig. 4C). Similar lithologies have 

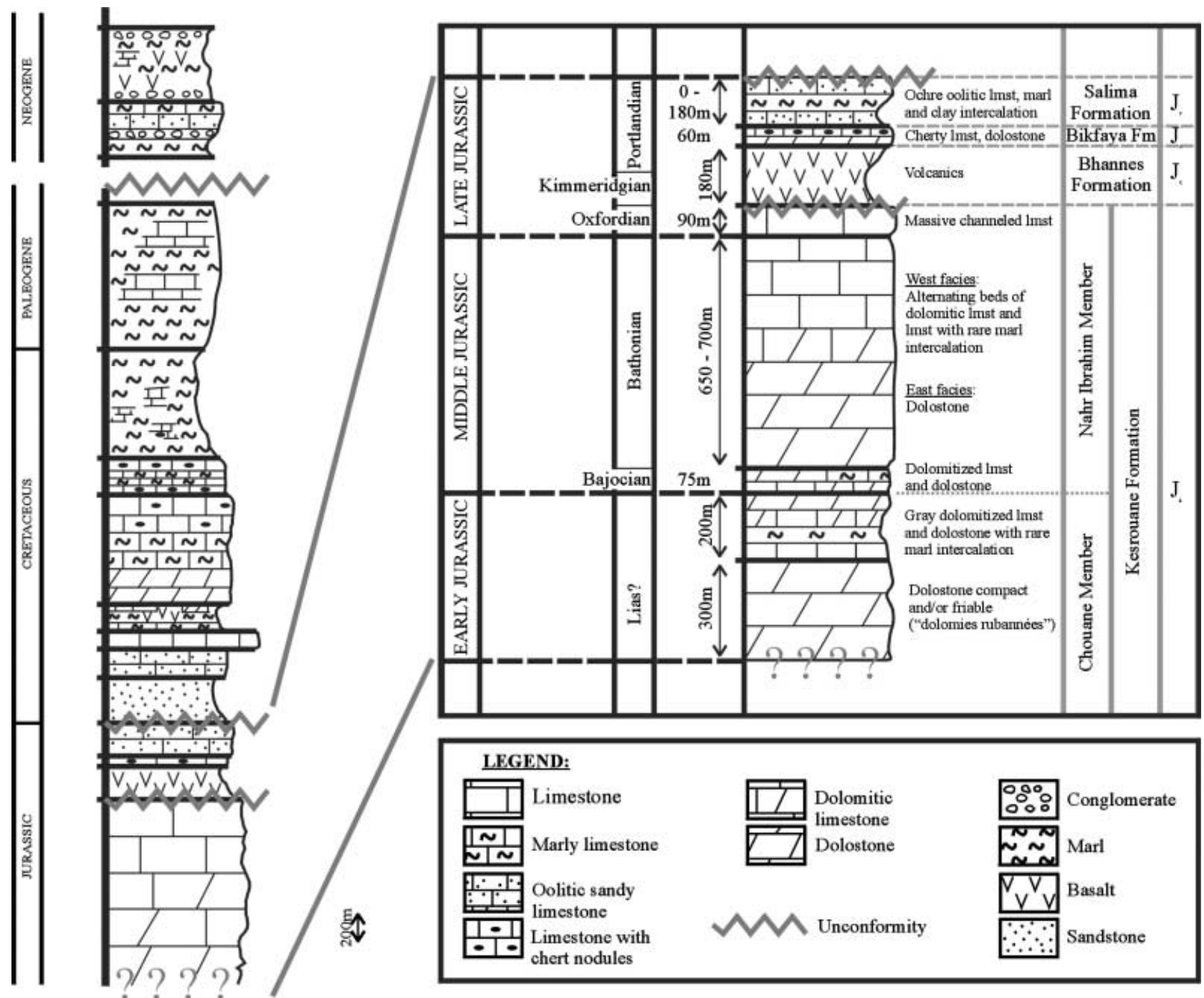

Fig. 3. Simplified litho-stratigraphical logs of the surface-exposed rock sequence in Lebanon (Dubertret, 1955) and the Jurassic sequence in Nahr Ibrahim, northern Lebanon (Renouard, 1951, 1955). 'Fm' is formation and 'lmst' is limestone.

been described by Buchbinder \& le Roux (1993) from Early Jurassic strata in Israel. Benjamini et al. (1993) also discussed depositional cycles in the Israeli Triassic sequence featuring similar rock facies. In the upper part, reef-related structures are found in thick biomicritic beds (bed thickness $>2 \mathrm{~m}$; Fig. 4D). The uppermost strata, the 'Massive channelled limestone beds' (Fig. 3), are marked by an erosional unconformable surface underlying the Kimmeridgian basalts of the Bhannes Formation - the contact is easily outlined in the field. Laws \& Wilson (1997) performed limited K-Ar dating on these basalts, which revealed an age of $\approx 148 \mathrm{Ma}$.

Renouard (1951, 1955) proposed a subdivision of the Kesrouane Formation into a basal part, characterized by the predominance of grey dolostones (Chouane Member), and an upper part less affected by dolomitization and mainly made up of micritic limestone (Nahr Ibrahim Member, Fig. 3). This simplistic picture becomes further complicated as a result of another type of dolostone that is strata destructive, prevailing throughout the Kesrouane Formation - the beige dolostone, named after its colour in hand specimen. The lack of genetic understanding of the dolostones located in the lower and upper parts of the formation at that time militated against acceptance of Renouard's proposal. Figure 5 is a detailed geological map covering part of the Nahr Ibrahim valley, where the two types of dolostones are exposed. While the grey dolostones are only found subaerially in the deepest parts of the valley, which incise the almost horizontally 

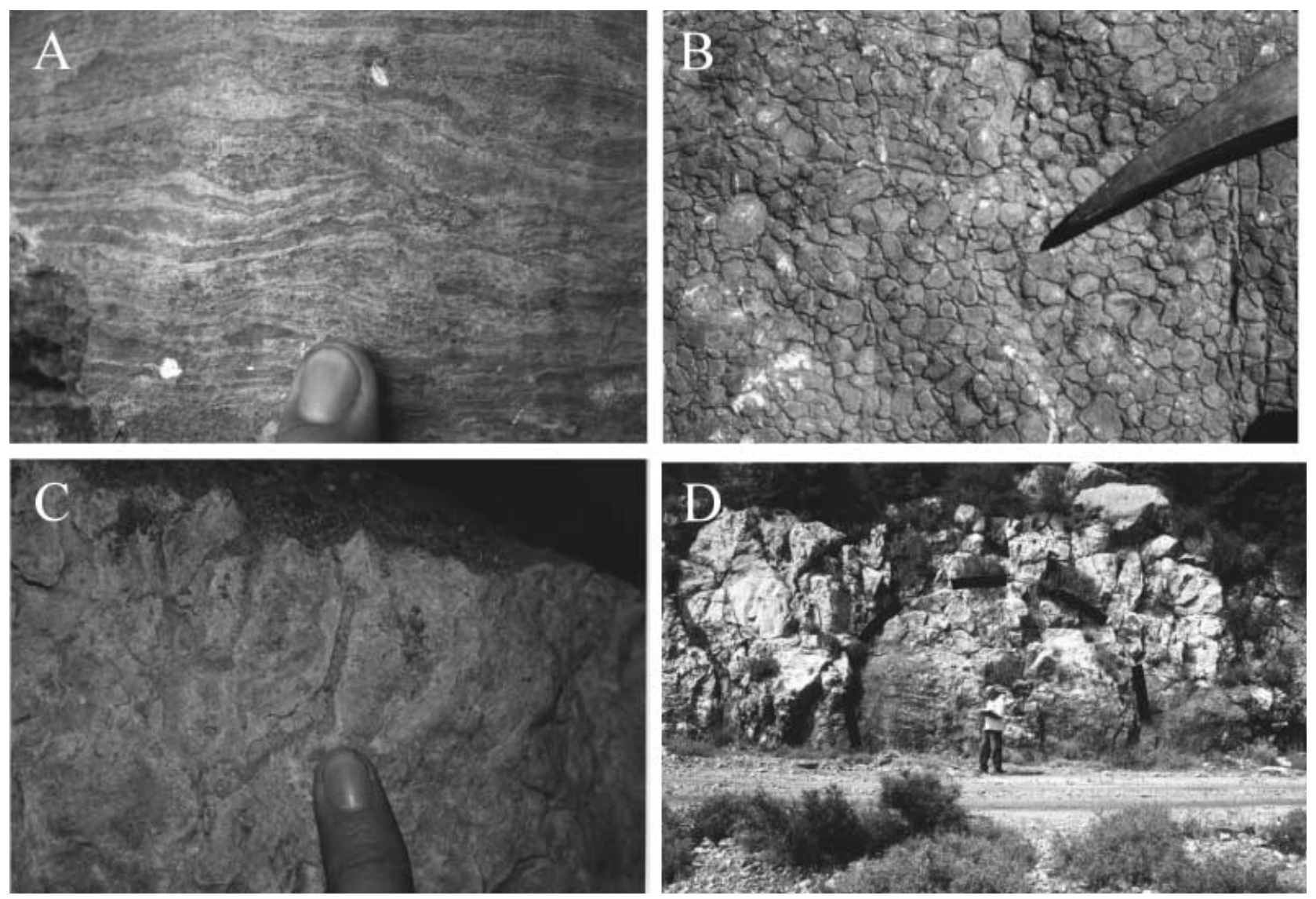

Fig. 4. Photographs showing sedimentological features characteristic of the Kesrouane Formation. (A) Cross-section of a stromatolitic bed (Nahr Ibrahim valley). (B) Oncolites in limestones showing stylolitic rims (Nahr Ibrahim valley; photo facing bed plane). (C) Fossilized plant roots below a palaeosol in the Daraya tunnel, Jeita (upper boundary of the grey dolomite). (D) A reef structure (knoll) in the upper part of the formation (Jeita) indicated by the detached line.

bedded Jurassic strata of northern Mount Lebanon, the beige dolostones form broad belts along major regional faults where Late Jurassic basalts are also present - locally post-dating the faults (Fig. 6). As they do not extend into adjacent post-Jurassic lithologies, these faults (as well as the associated basalts and beige dolostones) are of pre-Cretaceous age. In fact, the beige dolostones obliterate sedimentary fabrics and occur in any stratigraphical position, but are always within the Kesrouane Formation.

\section{PETROGRAPHY}

The limestones are predominantly bioclastic mudstone to wackestone with local and scarce horizons of bioclastic wackestone to packstone. Isopachous cement around grains and microfractures filled with very fine-sized calcite cement are present. Curvilinear veins including detrital carbonate infill phases, and dissolution vugs were also observed in these limestones. However, the major cement phase consists of equant calcite, precipitating in fossil moulds (e.g. corals and gastropods) and in the matrix porosity. The calcite cement displays drusy mozaic fabrics and syntaxial overgrowth (especially around crinoids). In the lower part of the exposed limestone sequence (just above the grey dolostones), compaction stylolites, cross-cutting and thus post-dating the above-mentioned cements, become very common. These stylolites are often masked by later phases of sparry calcite and poikilotopic cements, which exhibit red-orange dull CL patterns. Karst dissolution and non-luminescent spelean calcite cement are observed to post-date all the above-described diagenetic phases, corresponding therefore to the latest telogenetic period from Palaeogene to recent, during and after the final uplift of Mount Lebanon. 


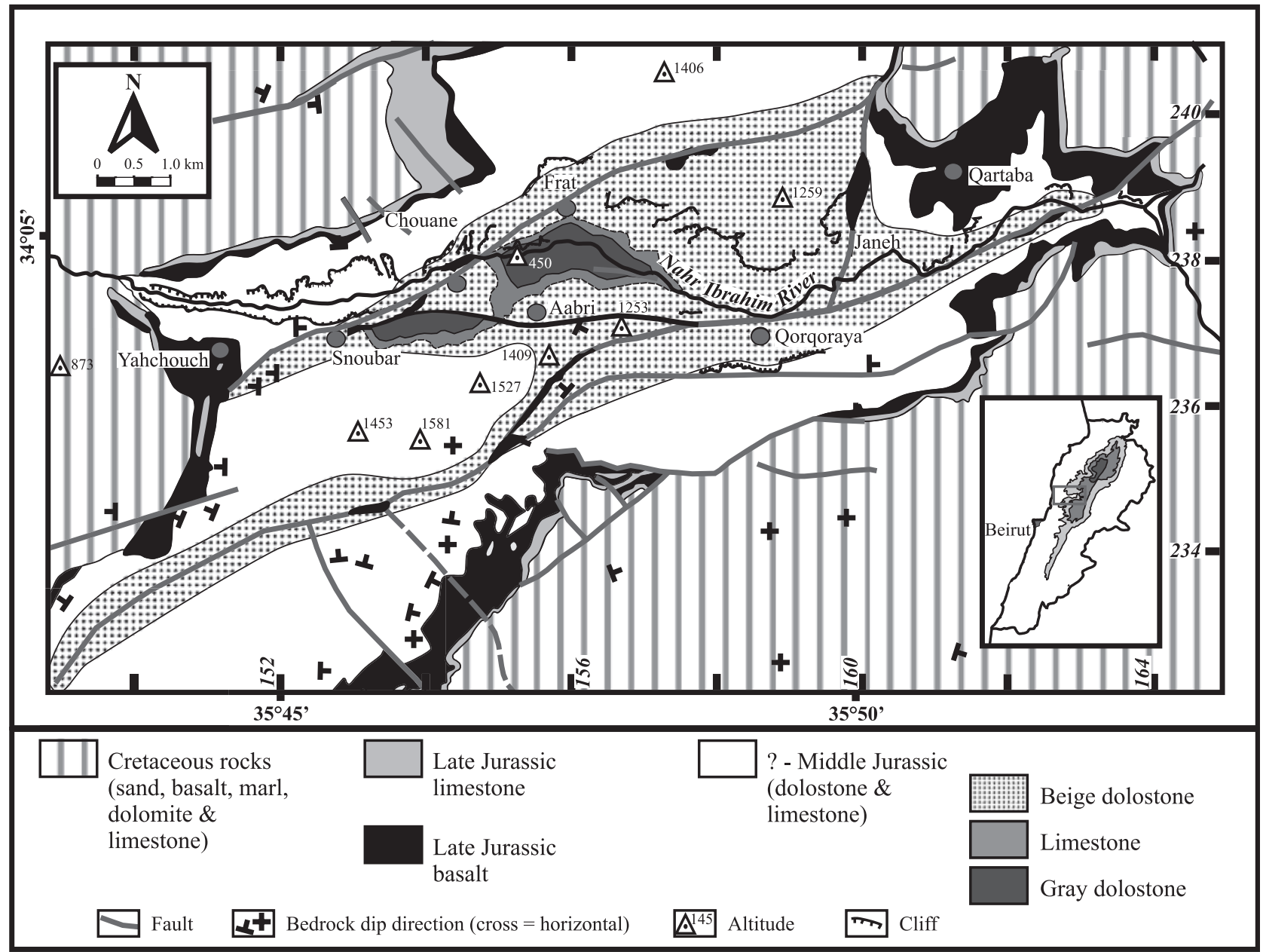

Fig. 5. Detailed geological map of the Nahr Ibrahim valley (northern Lebanon) featuring the extent of the Jurassic faults (see text for details), the exposures of the grey stratabound dolostone and the beige volcanism-associated dolostones. Note that the beige dolostones stretch along the Jurassic faults, where basalt is also present. The map is partially based on Renouard (1951) and Dubertret (1955).

\section{Grey vs. beige dolostones}

The grey stratabound dolostones consist of anhedral dolomite crystals, with sizes ranging between 10 and $200 \mu \mathrm{m}$ (Fig. 7A). The crystals show a clear internal structure with no nucleus-rim pattern. They have a polymodal non-planar texture and display a mottled red CL pattern (Fig. 7B). Iron oxides, pyrite, clay and organic matter occur abundantly, occluding the intercrystalline porosity. Under scanning electron microscopy (SEM), clays are observed between the dolomite crystals as intercrystalline pore infill and/or coating dolomite crystals (Fig. 7C). The grey dolostones locally exhibit pseudomorphs of nodular evaporite moulds and 'chicken wire' structures (Fig. 7D). Relict saddle dolomites form a thin corroded/calcitized layer covering the internal side of the evaporite moulds, while the rest of the moulds consists of dull luminescent sparry calcite. Bed parallel stylolites (BPS), stained with $\mathrm{Fe}$ oxides, are common in these rocks and apparently post-date dolomitization.

The beige dolostones consist of planar subhedral to euhedral dolomite crystals with an average size exceeding $400 \mu \mathrm{m}$ (typical of sucrosic dolomite; see Sibley \& Gregg, 1987; Fig. 8A-C). The crystals show cloudy centres surrounded by clear cement rims and generally show undulatory extinction typical of saddle dolomite (cf. Radke \& Mathis, 1980; Searl, 1989). Under SEM, these crystals show slightly curved faces in 'clean' claydevoid textures (Fig. 8B). They often display recrystallization-related fabrics (e.g. aggradational crystal growth, crystal welding and overgrowth). Crystals that align pores show alternating luminescence patterns indicating several distinct zones of dolomite cement (Fig. 8D), corresponding to 


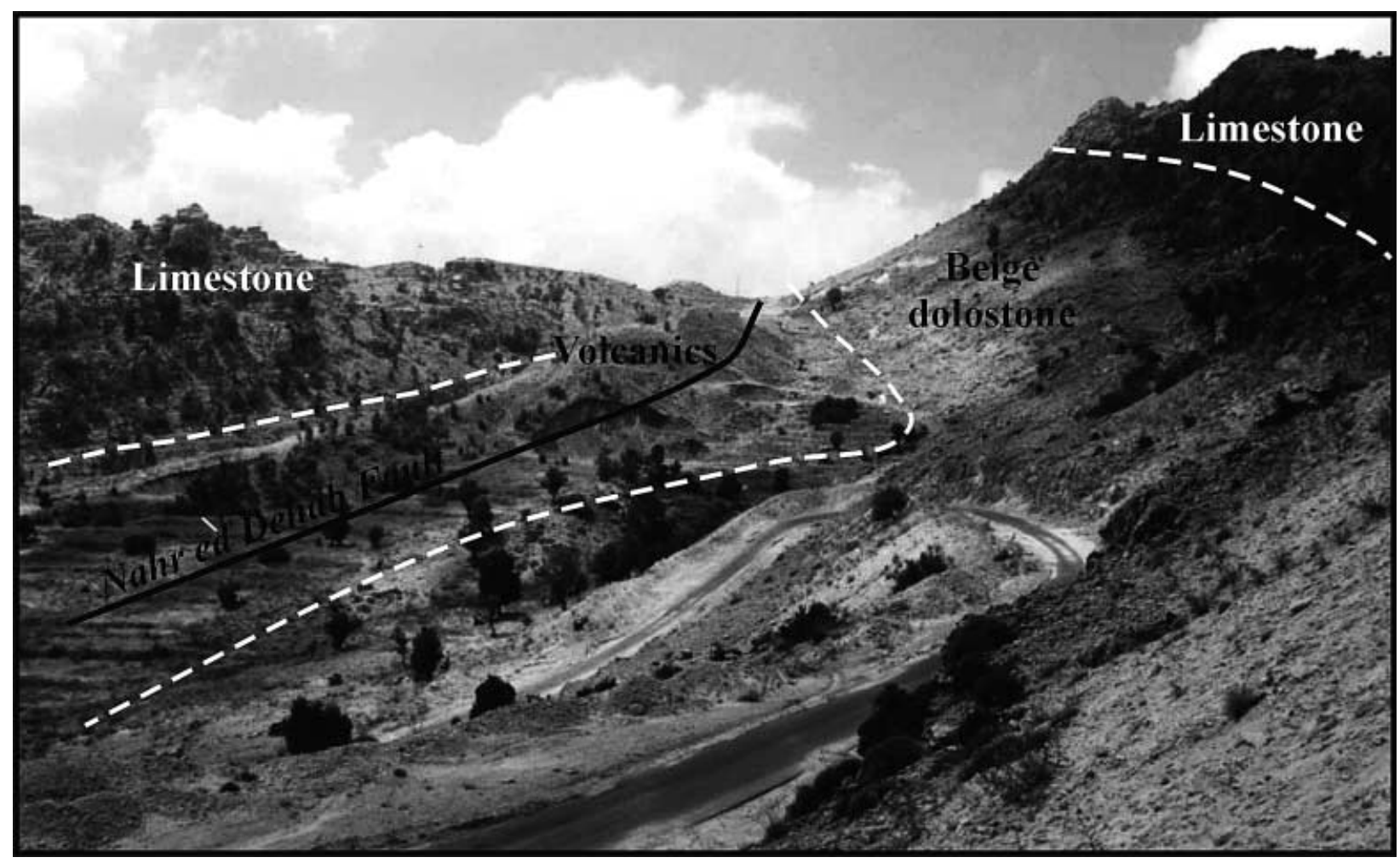

Fig. 6. Panoramic view showing the beige dolomitization front geometry in the field. The dolostone exposure stretches along pre-Cretaceous faults, where volcanics are present. Photograph taken in the Nahr Ibrahim region (Qahmez locality; looking east).

changes in pore fluid geochemistry and/or crystal growth rate. Bed-parallel stylolites (BPS) crosscut these rock textures and are therefore believed to post-date beige dolomite formation. The beige dolostones are also characterized by late calcitization (or dedolomitization; see Nader et al., 2003).

\section{Saddle dolomite veins}

Saddle dolomite veins essentially characterize the beige dolostones, although they are also present in grey dolostones and limestones (especially close to the beige dolostones). The frequency of such dolomites is more intense along the discussed pre-Cretaceous faults and decreases outwards. The saddle dolomite cement occurs in fractures with floating matrix fragments, very similar to breccia veins (Fig. 9A). These dolomites consist of clear planar euhedral dolomite crystals with an average size exceeding $1 \mathrm{~mm}$ (Fig. 9B), characterized by the typical undulatory extinction of saddle dolomites. The crystals display a basic mottled red CL pattern fashioned with pervasive bright recrystallized spots. Most of the crystals are affected by a later phase of non-luminescent calcitization (i.e. dolomite dissolution before calcite precipitation; Fig. 9B and C).

\section{GEOCHEMISTRY}

The geochemical data are listed in Table 1, including the $\mathrm{Sr}$ concentrations, the $\delta^{18} \mathrm{O}-\delta^{13} \mathrm{C}$ results (in \% V-PDB), ${ }^{87} \mathrm{Sr} /{ }^{86} \mathrm{Sr}$ values, the dolomite non-stoichiometry (in $\mathrm{M} \% \mathrm{CaCO}_{3}$ ) and crystal ordering (FWHM; full width of half maximum intensity) of 71 samples collected from the Kesrouane Formation (Jeita section). The data are grouped in seven categories according to their petrographic characteristics, namely: (1) bulk limestone; (2) grey dolostone; (3) beige dolostone; (4) saddle dolomite veins; (5) sparry calcite veins; (6) calcitized dolomite; and (7) spelean calcite.

\section{Dolomite stoichiometry and Sr content}

The stoichiometry of dolomite crystals is assessed by the degree of non-stoichiometry, expressed as mole percentage $(\mathrm{M} \%) \mathrm{CaCO}_{3}$, which seems not to be related to other petrographic parameters (e.g. rock type, dolomite crystal size, porosity, fossil component, insoluble residue; Lumsden \& 

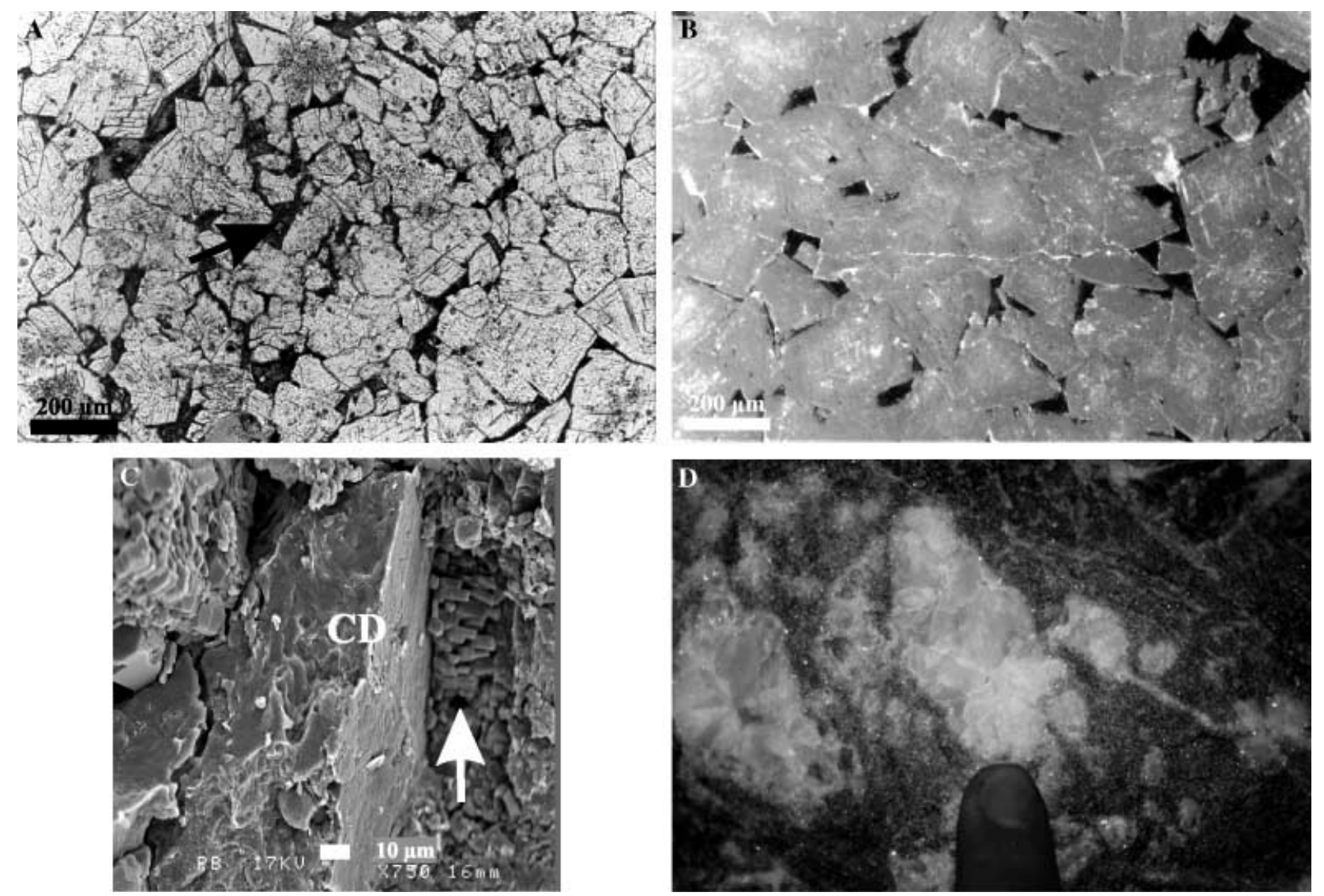

Fig. 7. Petrographic characteristics of the grey stratabound dolostones (Early Jurassic; Jeita). (A) Transmitted light photomicrograph showing non-planar crystals and abundance of intercrystalline clays with Fe oxides/hydroxides and pyrite (arrow). (B) CL photomicrograph showing a mottled red luminescence pattern. (C) SEM photograph showing a dolomite crystal coated with clays (CD); the arrow points to very fine dolomite crystals. (D) Photograph showing the local pseudomorphs of evaporite nodules and 'chicken-wire' structure.

Chimahusky, 1980). Carpenter (1980) and Land (1980) observed that less stable non-stoichiometric dolomites have an intrinsic thermodynamic drive to alter into more stable stoichiometric dolomite. Thus, a measure of non-stoichiometry gives an idea about the identity and stability of the dolomite (e.g. Sperber et al., 1984). Dorobek et al. (1993) and Nader et al. (2003) discussed the role of dolomite nonstoichiometry in initiating neomorphic alteration and/or calcitization.

The grey dolostones resulted in scattered values of both dolomite non-stoichiometry (between $52 \cdot 0$ and $57.5 \mathrm{M} \% \quad \mathrm{CaCO}_{3}$ ) and crystal ordering (FWHM; between 7.2 and 13.2; Fig. 10; Table 1). In contrast to stable dolomites, characterized by a non-stoichiometry ranging between 50.0 and $52.0 \mathrm{M} \% \quad \mathrm{CaCO}_{3}$ (Lumsden \& Chimahusky, 1980), the grey dolomites should be considered as less stable. This is not the case for the beige dolostones, which exhibit focused values confined to the $50 \cdot 5-52 \cdot 0 \mathrm{M} \% \mathrm{CaCO}_{3}$ and $12-14$
FWHM window (Fig. 10), evidence of more stoichiometric and well-ordered dolomite crystals. The saddle dolomite veins show two distinct populations: one that is non-stoichiometric and less ordered, fitting well with the grey dolostones; and another population that plots within the beige stoichiometric dolomite. The first population corresponds to veins in limestone relatively distant from the beige dolomitized zones, whereas the latter represents those veins sampled within the beige dolostones.

Based on average concentration values, a trend of decreasing $\mathrm{Sr}$ contents is deduced from limestones $(\approx 159$ p.p.m.) to grey dolostones $(\approx 73$ p.p.m. $)$ and beige dolostones $(\approx 40$ p.p.m.). The grey dolostones show an average $\mathrm{Sr}$ content that is almost equal to half that of the precursor limestones. Behrens \& Land (1972) suggested that the Sr distribution coefficient $\left(D^{\mathrm{Sr}}\right)$ for dolomites should be half that for calcite based on Sr substitution considerations. Moreover, Land (1980) argued that successive 

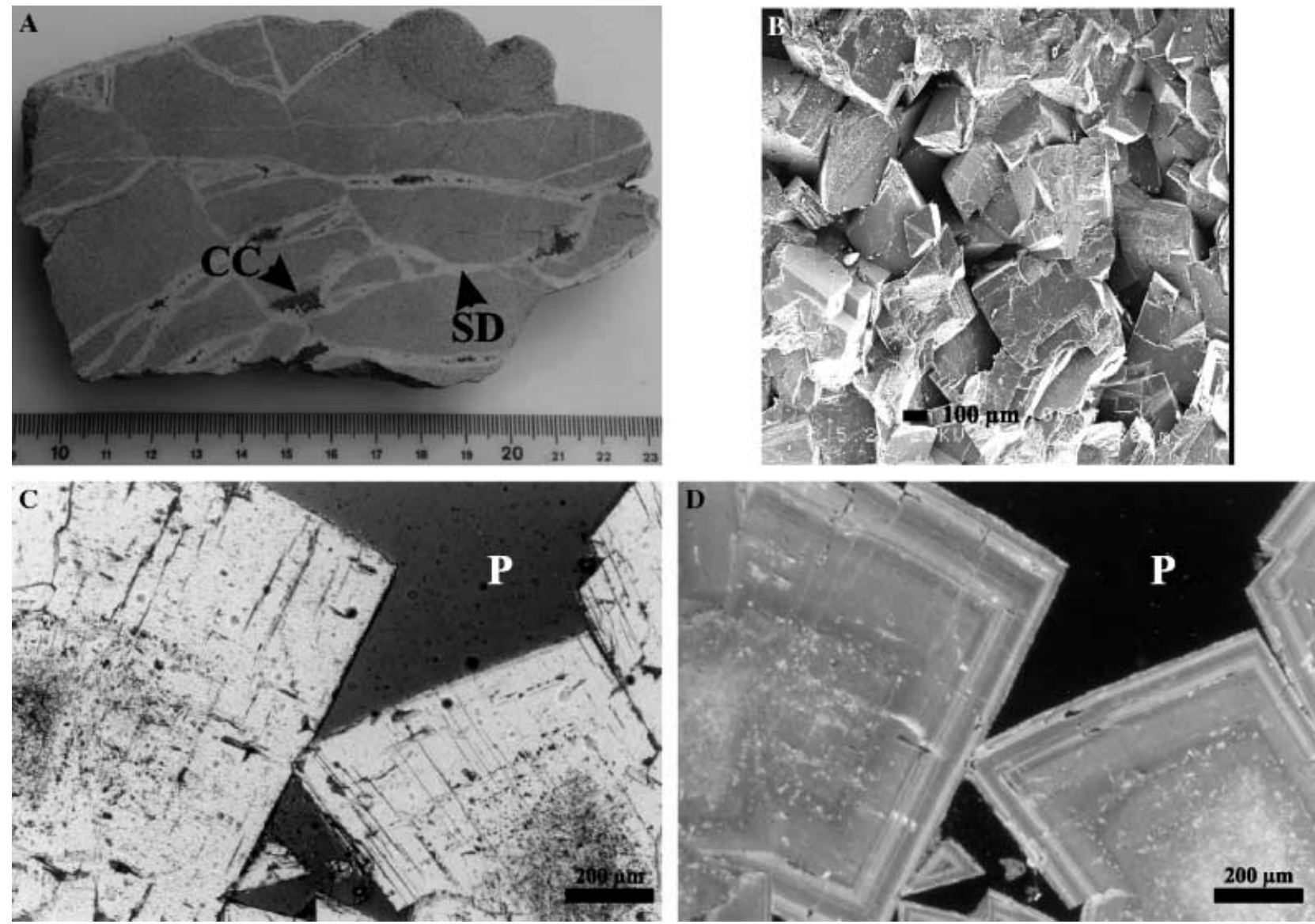

Fig. 8. Petrographic characteristics of the beige volcanism-associated dolostones (Late Jurassic). (A) Photograph of a polished/stained rock slab (Nahr Ibrahim) showing saddle dolomite veins (SD), hydrofractures and the later sparry (stained) calcite phase (CC). (B) SEM photograph showing the slight curvatures of the crystal faces and the intercrystalline porosity (Jeita). (C) The same sample observed under conventional transmitted light microscopy. Note the coarse-crystalline planar euhedral dolomite rhombs showing internal structure. (D) CL photomicrograph showing a mottled red luminescent crystal core, while the rims feature alternating CL patterns; (P) is pore (Jeita).

recrystallizations result in chemical 'purification' with decreasing $\mathrm{Sr}$ contents. Vahrenkamp \& Swart (1990) proposed a distribution coefficient of $0 \cdot 0118$ for the incorporation of $\mathrm{Sr}$ into dolomite (in marine settings). They formulated a relationship between the $\mathrm{D}^{\mathrm{Sr}}$ and the dolomite nonstoichiometry (expressed in $\mathrm{M} \% \mathrm{CaCO}_{3}$ ). The same approach was followed in this study (Fig. 11). Although the $\mathrm{Sr}$ concentrations are slightly lower than the data of Vahrenkamp \& Swart (1990), a similar trend of decreasing Sr content with decreasing non-stoichiometry (i.e. more stoichiometric dolomites) is observed (Fig. 11).

\section{Oxygen, carbon and strontium isotopes}

The Early Jurassic marine carbonate $\left(\mathrm{CaCO}_{3}\right)$ oxygen and carbon isotopic signature ranges from $-3 \cdot 0$ to $-1 \cdot 0 \%$ V-PDB and from $+1 \cdot 0$ to $+4 \cdot 0 \%$
V-PDB respectively (Fig. 12; Jenkyns et al., 2002). Comparatively, the $\delta^{18} \mathrm{O}$ signature of Early Jurassic marine dolomite ranges from -0.5 to $+1.5 \%$ V-PDB (Qing et al., 2001). The micritic limestones define a relatively wide $\delta^{18} \mathrm{O}$ compositional range ( $-5 \cdot 40$ to $-2 \cdot 65 \%$ V-PDB), whereas the $\delta^{13} \mathrm{C}(+0 \cdot 15$ to $+1 \cdot 71 \%$ o -PDB) values lie in a narrow range. $\delta^{18} \mathrm{O}$ values are slightly depleted compared with the original marine signature. The grey, beige and saddle dolomites show overlapping $\delta^{18} \mathrm{O}$ and $\delta^{13} \mathrm{C}$ values $(-9.04$ to $-7 \cdot 34 \%$ V-PDB and +1.76 to $+2 \cdot 41 \%$ o V-PDB respectively). The depleted $\delta^{18} \mathrm{O}$ values of these dolomites are not compatible with a marine shallow burial origin. However, their $\delta^{13} \mathrm{C}$ composition falls within the range of the $\delta^{13} \mathrm{C}$ signature of the Jurassic sea water.

The $\mathrm{Sr}$ isotope measurements of the limestones overlying the grey stratabound dolostones resulted in ${ }^{87} \mathrm{Sr} /{ }^{86} \mathrm{Sr}$ values of $0 \cdot 707095-0 \cdot 707131$ (Fig. 13). Accordingly, these limestones could be

(C) 2004 International Association of Sedimentologists, Sedimentology, 51, 339-360 

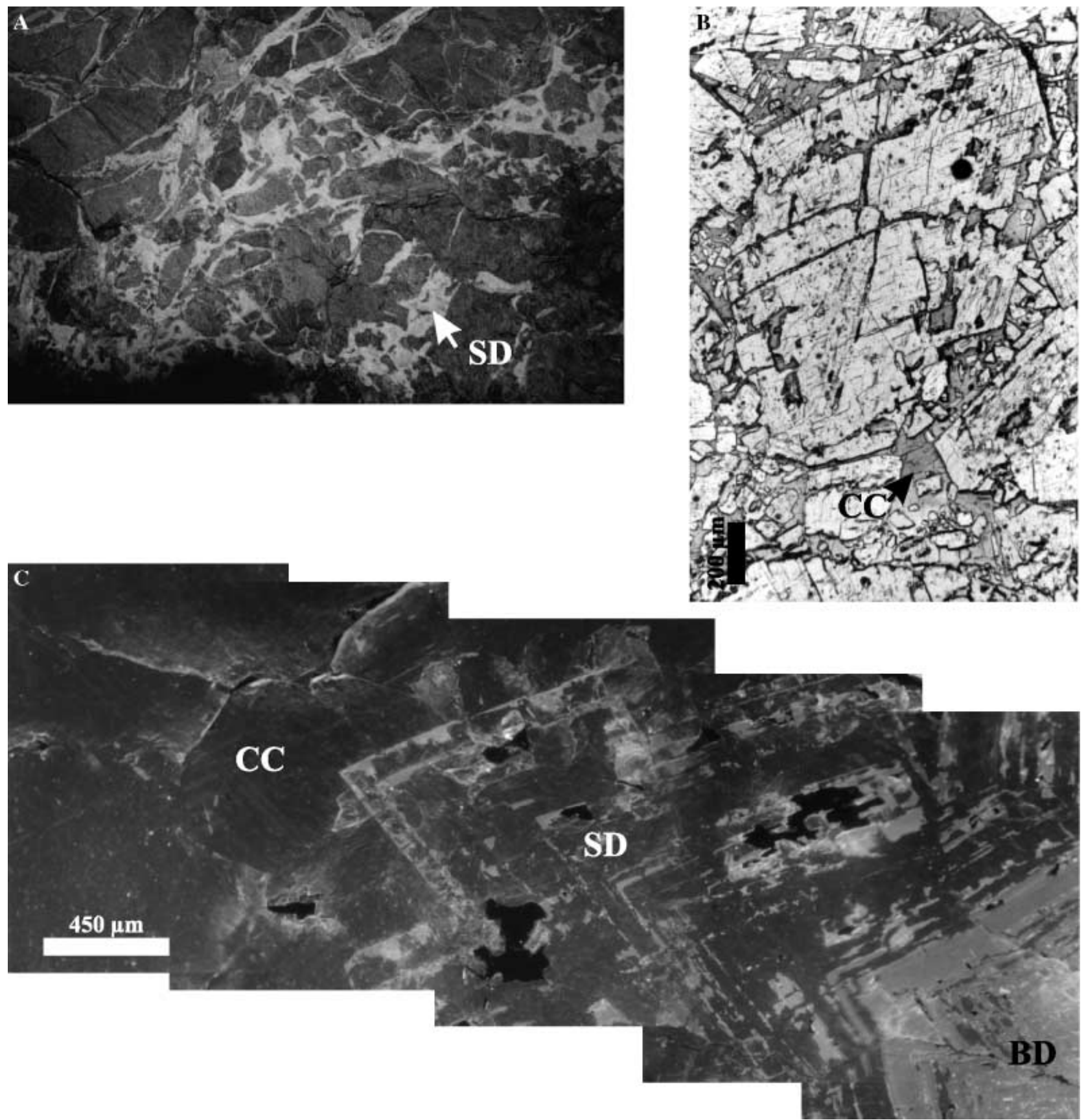

Fig. 9. Petrographic characteristics of the saddle dolomite veins (Late Jurassic). (A) Photograph of a section exposed along the Daraya tunnel wall in Jeita; SD is saddle dolomite. (B) Stained transmitted light photomicrograph showing a calcitized saddle dolomite crystal, CC is late calcite cement (Jeita). (C) CL photomicrograph showing a crystal continuum from mottled red luminescent beige dolomite (BD) to non-luminescent late calcite cement (CC), to calcitized saddle dolomite (SD), the relict fragments of the saddle dolomite still exhibit an alternating luminescent pattern (Jeita).

of Middle or Late Jurassic age (Bathonian or Kimmeridgian-Tithonian), by comparing their $\mathrm{Sr}$ isotope signature with the $\mathrm{Sr}$ sea-water curve (Burke et al., 1982; Jenkyns et al., 2002; Fig. 13). This is in agreement with micropalaeontological dating (Early Kimmeridgian; courtesy of Dr Rehakova, Comenius University, Bratislava,
Slovakia). The least recrystallized grey dolostone (based on petrography, non-stoichiometry and Sr concentration) resulted in a higher ${ }^{87} \mathrm{Sr} /{ }^{86} \mathrm{Sr}$ ratio (0.707455-0·707465) pointing towards an older Early Jurassic age or a Cretaceous age. As the grey dolostones occur below the limestones, they are of Early Jurassic age. The beige and saddle 
Table 1. Sr concentrations, $\delta^{18} \mathrm{O}$ and $\delta^{13} \mathrm{C}$ results, ${ }^{87} \mathrm{Sr} /{ }^{86} \mathrm{Sr}$ values, dolomite non-stoichiometry expressed by mole percentage $(\mathrm{M} \%) \mathrm{CaCO}_{3}$ and dolomite crystal ordering (expressed as FWHM) of the investigated rock types and diagenetic phases of the Kesrouane Formation (Lebanon).

\begin{tabular}{|c|c|c|c|c|c|c|c|}
\hline Serial no. & Sample & $\mathrm{Sr}$ & $\delta^{18} \mathrm{O}$ & $\delta^{13} \mathrm{C}$ & ${ }^{87} \mathrm{Sr} /{ }^{86} \mathrm{Sr}$ & $\mathrm{M} \% \mathrm{CaCO}_{3}$ & FWHM \\
\hline \multicolumn{8}{|l|}{ Limestone } \\
\hline 1 & $J-1$ & 134 & $-5 \cdot 18$ & $+1 \cdot 38$ & - & & \\
\hline 2 & $J-4$ & 135 & $-5 \cdot 40$ & $+1 \cdot 40$ & - & & \\
\hline 3 & $\mathrm{~J}-7$ & 186 & $-4 \cdot 44$ & $+1 \cdot 42$ & - & & \\
\hline 4 & $J-9$ & 130 & - & - & - & & \\
\hline 5 & JT-3 & 148 & $-3 \cdot 85$ & $+0 \cdot 62$ & - & & \\
\hline 6 & $J-10$ & 112 & - & - & - & & \\
\hline 7 & $\mathrm{~J}-12$ & 180 & - & - & - & & \\
\hline 8 & JT-4 & 125 & $-4 \cdot 64$ & $+1 \cdot 83$ & - & & \\
\hline 9 & $J-19$ & 149 & - & - & - & & \\
\hline 10 & $\mathrm{~J}-23$ & 113 & $-4 \cdot 76$ & $+0 \cdot 15$ & - & & \\
\hline 11 & JT-6 & 150 & - & - & - & & \\
\hline 12 & $J-29-m$ & 193 & $-3 \cdot 84$ & $+1 \cdot 35$ & - & & \\
\hline 13 & JT-7 & 167 & $-3 \cdot 66$ & $+1 \cdot 67$ & - & & \\
\hline 14 & RB-13 & 297 & $-2 \cdot 65$ & $+1 \cdot 71$ & $0 \cdot 707095$ & & \\
\hline 15 & JT-8 & 158 & $-2 \cdot 68$ & $+1 \cdot 34$ & $0 \cdot 707131$ & & \\
\hline \multicolumn{8}{|c|}{ Grey dolostone } \\
\hline 16 & JR-8 & 104 & $-8 \cdot 16$ & +1.94 & - & $56 \cdot 50$ & $10 \cdot 50$ \\
\hline 17 & $J-33^{\prime}$ & 86 & $-9 \cdot 04$ & $+2 \cdot 11$ & - & $57 \cdot 50$ & $9 \cdot 44$ \\
\hline 18 & $J-37$ & 56 & - & - & - & $53 \cdot 67$ & $8 \cdot 26$ \\
\hline 19 & $\mathrm{~J}-38$ & 66 & $-7 \cdot 82$ & $+2 \cdot 08$ & - & $54 \cdot 50$ & $7 \cdot 42$ \\
\hline 20 & $J-39 p$ & 101 & $-8 \cdot 64$ & $+2 \cdot 05$ & - & $53 \cdot 67$ & $9 \cdot 17$ \\
\hline 21 & $\mathrm{~F}^{\prime}$ & 104 & - & - & - & $56 \cdot 00$ & $13 \cdot 20$ \\
\hline 22 & $\mathrm{D}$ & 47 & - & - & - & - & - \\
\hline 23 & B & 78 & - & - & - & $55 \cdot 00$ & $7 \cdot 68$ \\
\hline 24 & S2 & 28 & $-8 \cdot 49$ & $+1 \cdot 90$ & - & $52 \cdot 33$ & $10 \cdot 00$ \\
\hline 25 & $\mathrm{Zb}$ & 67 & $-7 \cdot 34$ & $+2 \cdot 23$ & - & - & - \\
\hline 26 & $\mathrm{Zd}$ & 79 & $-8 \cdot 34$ & $+2 \cdot 20$ & - & $54 \cdot 67$ & $7 \cdot 22$ \\
\hline 27 & 40-mat & 73 & $-8 \cdot 69$ & $+2 \cdot 25$ & - & - & - \\
\hline 28 & S4 & 48 & $-8 \cdot 76$ & $+2 \cdot 14$ & - & $52 \cdot 00$ & $11 \cdot 79$ \\
\hline 29 & JR-4 & 74 & $-8 \cdot 28$ & $2 \cdot 16$ & - & $52 \cdot 25$ & $11 \cdot 38$ \\
\hline 30 & Y & 103 & $-8 \cdot 97$ & $+1 \cdot 97$ & $0 \cdot 707455$ & $55 \cdot 00$ & $8 \cdot 63$ \\
\hline 31 & $J R-1 b$ & 74 & $-7 \cdot 96$ & $+2 \cdot 24$ & - & $54 \cdot 22$ & $10 \cdot 31$ \\
\hline 32 & $450-2 a$ & 67 & - & - & - & $55 \cdot 78$ & $7 \cdot 99$ \\
\hline 33 & $450-6$ & 52 & - & - & $0 \cdot 707465$ & $54 \cdot 67$ & $8 \cdot 47$ \\
\hline \multicolumn{8}{|c|}{ Beige dolostone } \\
\hline 34 & B-0 & 57 & $-8 \cdot 57$ & $+2 \cdot 32$ & - & $51 \cdot 00$ & $13 \cdot 20$ \\
\hline 35 & $\mathrm{~J}-34$ & 42 & $-8 \cdot 20$ & $+2 \cdot 27$ & $0 \cdot 707661$ & $51 \cdot 13$ & $12 \cdot 17$ \\
\hline 36 & JR-5m & 57 & $-8 \cdot 84$ & $+2 \cdot 09$ & - & $51 \cdot 75$ & $13 \cdot 75$ \\
\hline 37 & $\mathrm{~J}-35$ & 22 & - & - & - & $50 \cdot 67$ & $12 \cdot 95$ \\
\hline 38 & $\mathrm{~J}-36$ & 42 & - & - & - & $51 \cdot 33$ & $13 \cdot 07$ \\
\hline 39 & JT-9 & 27 & $-8 \cdot 53$ & $+2 \cdot 41$ & - & - & - \\
\hline 40 & JT-S5 & 51 & $-8 \cdot 18$ & $+2 \cdot 27$ & - & $51 \cdot 00$ & $13 \cdot 20$ \\
\hline 41 & JT-10 & 39 & - & - & - & $51 \cdot 33$ & $13 \cdot 73$ \\
\hline 42 & $\mathrm{X}$ & 42 & $-8 \cdot 30$ & $+2 \cdot 25$ & - & & \\
\hline 43 & $\mathrm{Za}$ & 28 & $-7 \cdot 41$ & $+2 \cdot 39$ & - & $50 \cdot 83$ & $13 \cdot 20$ \\
\hline 44 & JR-1a & 81 & $-8 \cdot 42$ & $+2 \cdot 13$ & - & $55 \cdot 00$ & $10 \cdot 82$ \\
\hline 45 & $J-41$ & 47 & - & - & - & $50 \cdot 83$ & $14 \cdot 33$ \\
\hline 46 & $J-42$ & 40 & $-8 \cdot 78$ & $+2 \cdot 27$ & - & - & - \\
\hline 47 & $J-43$ & 36 & - & - & - & $51 \cdot 58$ & $12 \cdot 22$ \\
\hline 48 & JT-11 & 27 & $-8 \cdot 25$ & $+2 \cdot 16$ & - & - & - \\
\hline 49 & $450-5$ & 23 & - & - & - & $51 \cdot 50$ & $13 \cdot 45$ \\
\hline 50 & $J-44$ & 31 & - & - & - & $51 \cdot 25$ & $12 \cdot 85$ \\
\hline 51 & $\mathrm{~J}-45$ & 27 & $-8 \cdot 19$ & $+2 \cdot 24$ & $0 \cdot 707725$ & - & - \\
\hline \multicolumn{8}{|c|}{ Saddle dolomite veins } \\
\hline 52 & $J-28-\mathrm{v}$ & 78 & - & - & - & $55 \cdot 17$ & $5 \cdot 69$ \\
\hline
\end{tabular}


Table 1. (Continued).

\begin{tabular}{|c|c|c|c|c|c|c|c|}
\hline Serial no. & Sample & $\mathrm{Sr}$ & $\delta^{18} \mathrm{O}$ & $\delta^{13} \mathrm{C}$ & ${ }^{87} \mathrm{Sr} /{ }^{86} \mathrm{Sr}$ & $\mathrm{M} \% \mathrm{CaCO}_{3}$ & FWHM \\
\hline 53 & JT-7-v & 80 & $-8 \cdot 72$ & $+2 \cdot 21$ & - & $55 \cdot 17$ & $2 \cdot 44$ \\
\hline 54 & $J-29 v$ & 76 & $-8 \cdot 37$ & $+2 \cdot 01$ & $0 \cdot 707707$ & $53 \cdot 50$ & $7 \cdot 92$ \\
\hline 55 & $J-34 d v$ & - & $-8 \cdot 87$ & $+1 \cdot 91$ & - & - & - \\
\hline 56 & J35-v & 12 & - & - & - & $51 \cdot 00$ & $11 \cdot 58$ \\
\hline 57 & $J R-5 d v$ & 57 & $-8 \cdot 72$ & $+2 \cdot 03$ & - & 51.67 & $12 \cdot 57$ \\
\hline 58 & $J-38 b$ & - & $-8 \cdot 70$ & $+1 \cdot 76$ & - & - & - \\
\hline 59 & $\mathrm{~S} 4 \mathrm{v}$ & - & $-7 \cdot 47$ & $+2 \cdot 00$ & - & - & - \\
\hline 60 & $J-42 b$ & - & $-8 \cdot 92$ & $+2 \cdot 02$ & - & - & - \\
\hline 61 & $J-45 v$ & - & - & - & $0 \cdot 707844$ & - & - \\
\hline \multicolumn{8}{|c|}{ Sparry calcite } \\
\hline 62 & RB-1v & 94 & $-9 \cdot 52$ & $+0 \cdot 76$ & - & & \\
\hline 63 & R-8ca & 104 & $-9 \cdot 22$ & $+0 \cdot 73$ & $0 \cdot 707828$ & & \\
\hline 64 & JL-33 & - & $-11 \cdot 20$ & $+1 \cdot 00$ & - & & \\
\hline 65 & $\mathrm{~J}-20$ & 53 & $-5 \cdot 59$ & $-2 \cdot 32$ & - & $54 \cdot 17$ & $8 \cdot 80$ \\
\hline \multicolumn{8}{|c|}{ Calcitized dolostone } \\
\hline 66 & JT-5 & 51 & $-5 \cdot 38$ & $-2 \cdot 40$ & - & $54 \cdot 67$ & $9 \cdot 81$ \\
\hline 67 & JD-17 & - & $-5 \cdot 16$ & $-2 \cdot 64$ & - & - & - \\
\hline 68 & $\mathrm{~J}-21$ & 27 & $-5 \cdot 44$ & $-5 \cdot 11$ & - & - & - \\
\hline 69 & $J-22$ & 75 & $-7 \cdot 54$ & $+2 \cdot 12$ & $0 \cdot 707760$ & $55 \cdot 17$ & $12 \cdot 00$ \\
\hline \multicolumn{8}{|c|}{ Spelean calcite } \\
\hline 70 & $J-20 v$ & - & $-6 \cdot 27$ & $-7 \cdot 00$ & - & & \\
\hline 71 & RK-1 & - & $-6 \cdot 21$ & $-9 \cdot 10$ & - & & \\
\hline
\end{tabular}

Sr is expressed in p.p.m., $\delta^{18} \mathrm{O}$ and $\delta^{13} \mathrm{C}$ in \%o V-PDB. '-' is 'not analysed'.

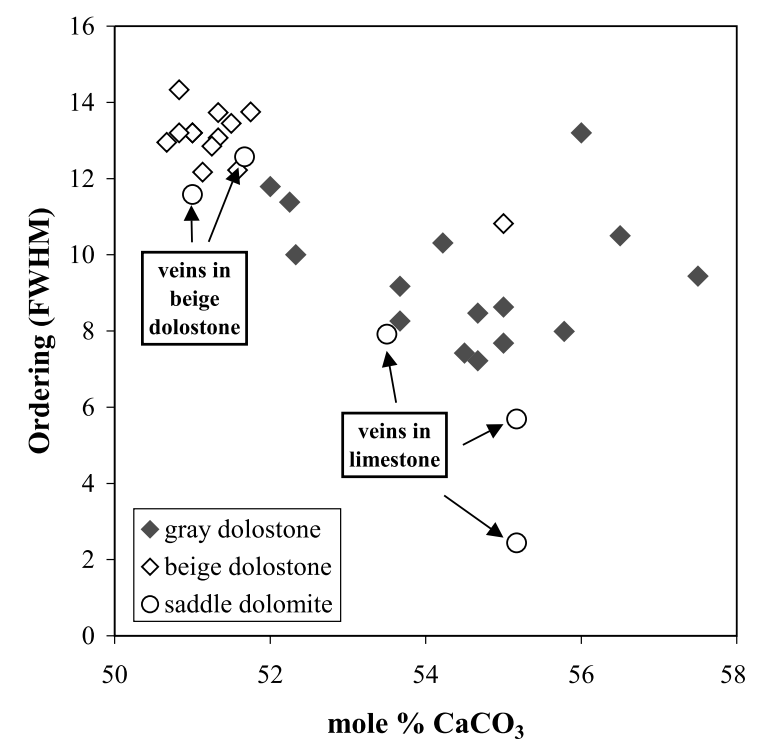

Fig. 10. Dolomite non-stoichiometry expressed by mole percentage $(\mathrm{M} \%) \mathrm{CaCO}_{3}$ vs. crystal ordering (expressed as FWHM - full width of half maximum intensity of XRD peaks) diagram for the grey, beige and saddle dolomites. Note the scattered pattern of the grey dolomite values compared with the clustered values of the beige dolomite.

dolomites exhibit recrystallization textures and are restricted to pre-Cretaceous faults, where Late Jurassic basalt occurs. These dolomites resulted in higher ${ }^{87} \mathrm{Sr} /{ }^{86} \mathrm{Sr}$ values of $0 \cdot 7077-0 \cdot 7078$, compared with the $\mathrm{Sr}$ isotopic composition of carbonates from Late Jurassic sea water $\left({ }^{87} \mathrm{Sr} /{ }^{86} \mathrm{Sr}=0 \cdot 7068-0 \cdot 7072\right) . \quad$ Therefore, their ${ }^{87} \mathrm{Sr} /{ }^{86} \mathrm{Sr}$ values are not suitable for dating and rather suggest influx of slightly radiogenic fluids.

\section{MICROTHERMOMETRY}

Beige and saddle dolomites contain abundant secondary one-phase inclusions and less abundant primary and/or pseudosecondary two-phase inclusions $(N=92$; size ranging from 3 to $30 \mu \mathrm{m})$. The measurements of homogenization temperature $\left(\mathrm{T}_{\mathrm{H}}\right)$ revealed a distribution range between 50 and $140{ }^{\circ} \mathrm{C}$; the highest frequency interval covers 50-90 ${ }^{\circ} \mathrm{C}$ (Fig. 14A). Results of measured fluid inclusions enclosed in saddle dolomite veins were grouped according to the corresponding host rocks (i.e. limestone, grey and beige dolostones); a fourth group was set for the measured beige rock matrix dolomite $(N=11$; size between 3 and $7 \mu \mathrm{m}$; Fig. 14A). The $\mathrm{T}_{\mathrm{H}}$ results of all these groups plot in parallel patterns. The beige matrix dolomites show a narrower $\mathrm{T}_{\mathrm{H}}$ range (between 70 and $80^{\circ} \mathrm{C}$, with the exception of one value of $\left.50{ }^{\circ} \mathrm{C}\right)$. Twenty measurements of the final melt temperature $\left(\mathrm{T}_{\mathrm{M}}\right)$ were successful, covering the 


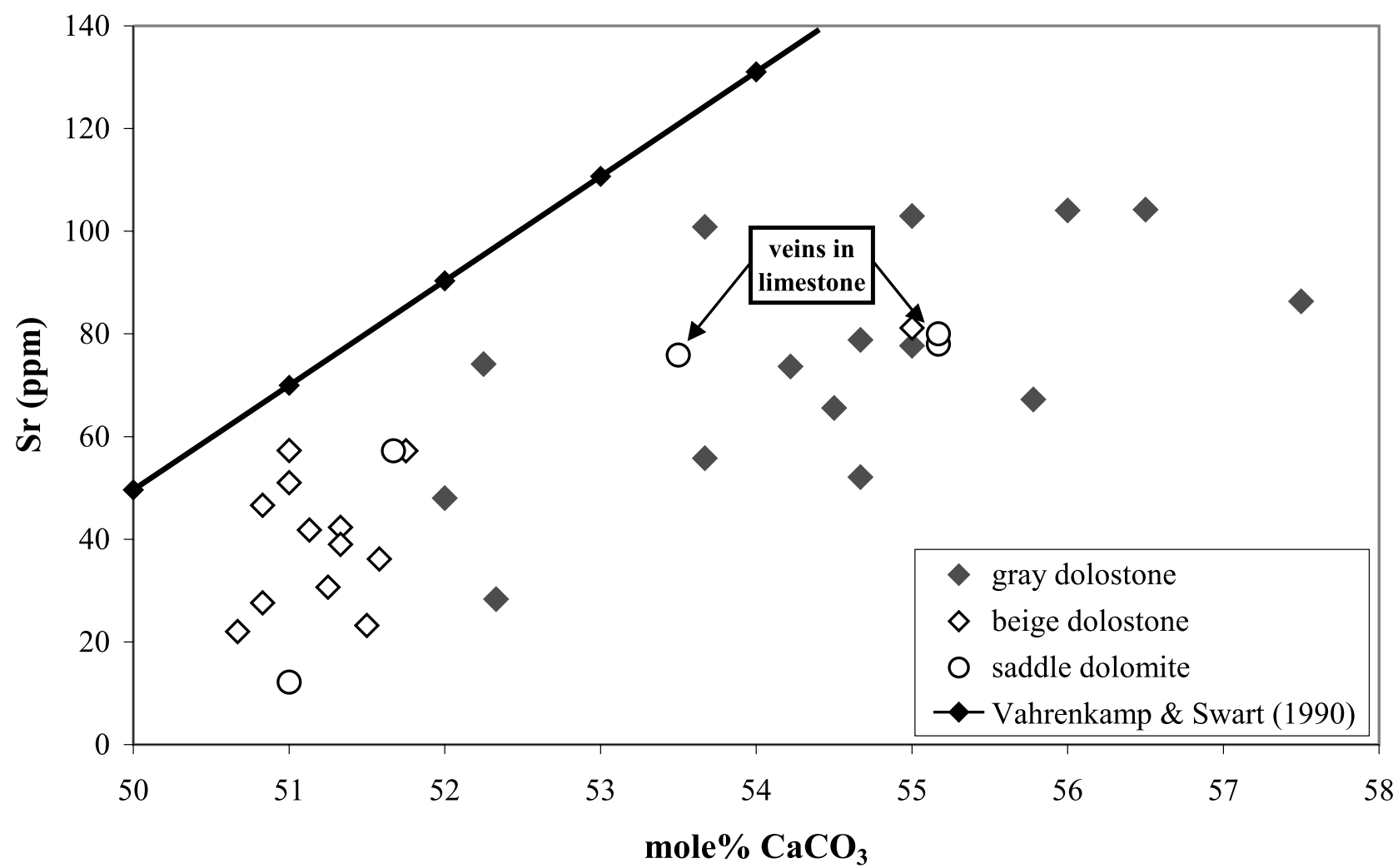

Fig. 11. Dolomite non-stoichiometry $\left(\mathrm{M} \% \mathrm{CaCO}_{3}\right)$ vs. Sr concentration (p.p.m.) of the Kesrouane Formation dolostones and related constituents. The corresponding linear trend proposed by Vahrenkamp \& Swart (1990) is included.

discussed groups with the exception of the beige matrix dolomite. Subsequently, the corresponding salinity values were calculated (cf. Bodnar, 1993). Figure 14B shows $\mathrm{T}_{\mathrm{H}}\left({ }^{\circ} \mathrm{C}\right)$ vs. inferred salinity (in eq. wt $\% \mathrm{NaCl}$ ) of the various measured inclusions from saddle dolomites in limestones and dolostones. These fluid inclusions have salinities ranging between 3.5 and $12.0 \mathrm{wt} \%$ $\mathrm{NaCl}$ (i.e. up to three times more saline than normal sea water). Such fluids may represent sea water and/or evaporated sea water in a lagoonal setting or mixing with subsurface brine. In terms of nomenclature, fluids having a similar range of salinity (below the gypsum saturation level) are termed mesosaline and may be refluxed into carbonate lagoon facies similarly to hypersaline brines (> 12\% NaCl; Simms, 1984).

\section{DISCUSSION}

The burial history of the Kesrouane Formation in northern Mount Lebanon, based on stratigraphic and facies consideration, is reported in Fig. 15. In Early Jurassic times, the Kesrouane carbonates were deposited within the extensive, but shallow,
Palmyride basin. This situation was maintained until the Late Jurassic volcanism and local uplift, which were associated with regional tensional tectonic movements along the continental margin of the Tethyan sea (Stampfli et al., 2001; Walley, 2001). Such extensional tectonics may have resulted in local high geothermal gradients ( $\approx 45-55{ }^{\circ} \mathrm{C} \mathrm{km}^{-1}$; Ayalon \& Longstaffe, 1995). The eroded (karstified) topmost part of the uplifted formation became an extensive recharge area for meteoric water. Sea-water fluctuation and/or uplift in the Late Jurassic-Early Cretaceous resulted in the deposition of the various alternating carbonate and clastic formations. These are characterized by local volcanics, especially in the northern part of the study area. Burial resumed after the Early Cretaceous. The maximum burial depth $(\approx 3000 \mathrm{~m})$ must have occurred in the Late Cretaceous just before the final tectonic uplift and emergence of Mount Lebanon (associated with the Syrian Arc deformations; Walley, 2001; Wood, 2001).

The stratabound grey dolostones include local pseudomorphs of evaporite nodules predating bed-parallel stylolites. They are characterized by non-stoichiometric unordered dolomite crystals, 


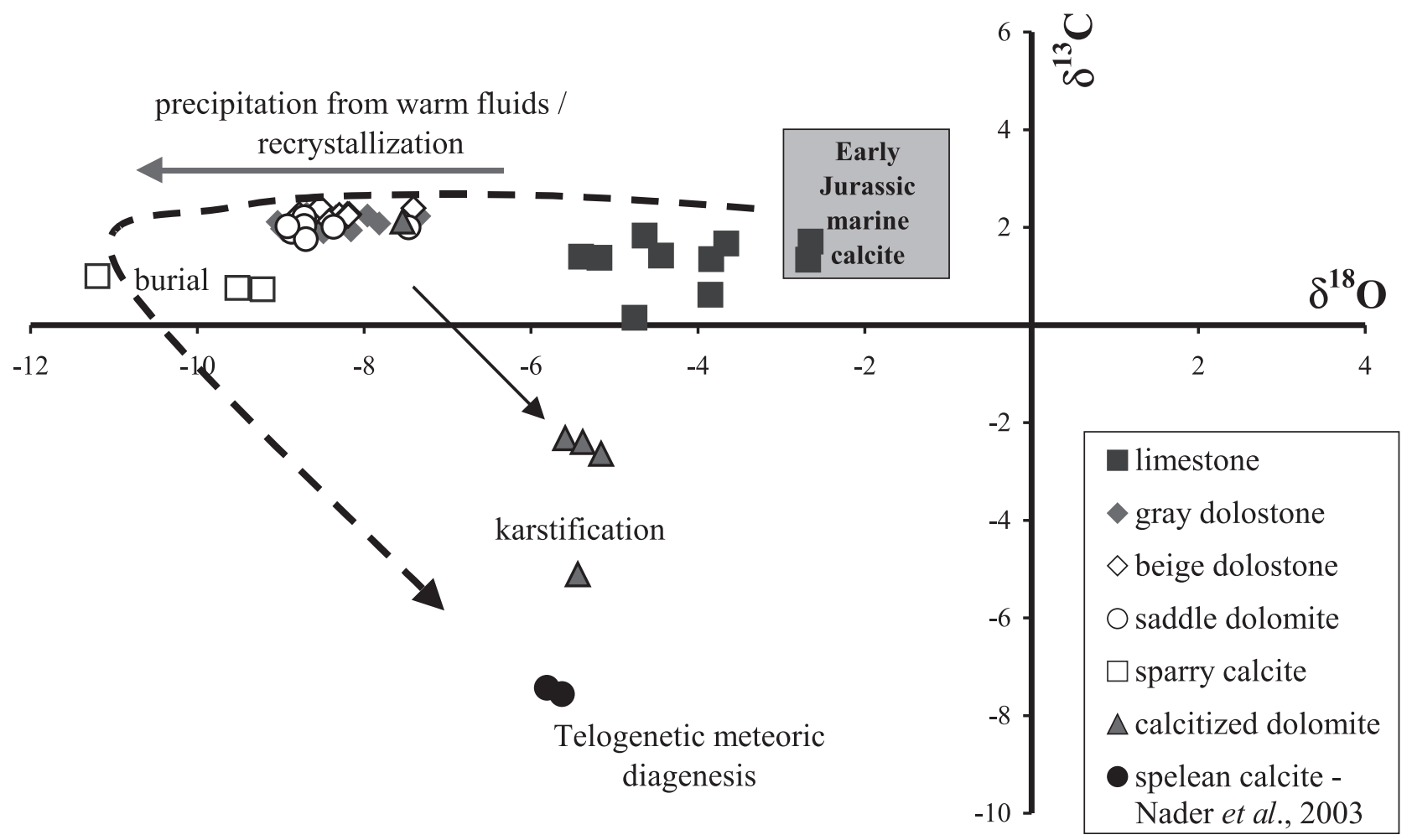

Fig. 12. Oxygen and carbon isotopic compositions of the Kesrouane Formation constituents and diagenetic phases (standardized to V-PDB). The Early Jurassic marine signature for calcite and dolomite is also reported - squares; from Jenkyns et al. (2002) and Qing et al. (2001). The dashed arrow summarizes the paragenetic evolution (from limestone to dolomite, burial calcite cement and, finally, karst/meteoric cement; data from Nader et al., 2003).

Fe oxides and clays, and high concentrations of $\mathrm{Fe}, \mathrm{K}$ and IR\% (insoluble residue; see Nader et al., 2003). Limestones of similar age, spared from dolomitization, are characterized by mudstone-dominated stromatolitic and oncolitic textures. This coincides with the relatively low global sea-water level of the Late Triassic-Early Jurassic times, and evaporitic conditions throughout the whole eastern Mediterranean and Middle East regions. Thus, the grey dolostones are interpreted as being the product of early seepagereflux dolomitization (before stylolitization) from evaporated hypersaline to mesosaline sea-water (in lagoons and/or shallow-marine settings), whereby the required source of $\mathrm{Mg}$ for dolomitization is provided. Reflux dolomitization is also supported by the non-stoichiometric nature of the grey dolomites. Their relatively coarse crystal sizes and low $\delta^{18} \mathrm{O}$ values, compared with the typical reflux dolomicrites, is interpreted as being the result of later recrystallization. In fact, the original oxygen isotopic composition might have been reset during the beige saddle dolomitization (Late Jurassic, discussed below), whereby their depleted $\delta^{18} \mathrm{O}$ values suggest recrystallization at higher temperatures. For instance, if these dolomites were precipitated from sea water, their $\delta^{18} \mathrm{O}$ values may point towards formation temperatures between 80 and $100{ }^{\circ} \mathrm{C}$ (see Adams et al., 2000).

During and/or after the grey dolomitization, volcanism was already initiated in Mount Lebanon, although it did not culminate before the Kimmeridgian (Late Jurassic; Dubertret, 1955). The Liassic-Oxfordian rock mass (grey dolostones and shallow bioclastic micrite) was therefore fractured and faulted at that time. Field observation revealed that the beige dolostones mostly occur along regional pre-Cretaceous faults, and are commonly associated with saddle dolomite veins. Buchbinder et al. (1984) discussed similar saddle dolomites ('vug filling') in Jurassic carbonates in Israel, suggesting co-precipitation with the dolostone host rock (similar to the beige dolostone in Lebanon) and/or interaction with successive circulation fluids. The beige dolostones are characterized by a sucrosic coarse-crystalline texture with slightly curved, stoichiometric and well-ordered crystals. According to fluid inclusion analyses, these dolomites precipitated from mesosaline fluids (up to three times more saline than average sea water). The 
Fig. 13. $87 \mathrm{Sr} /{ }^{86} \mathrm{Sr}$ isotopic values of the Kesrouane Formation constituents and diagenetic phases reported on the sea-water Sr composition/time curve plot.

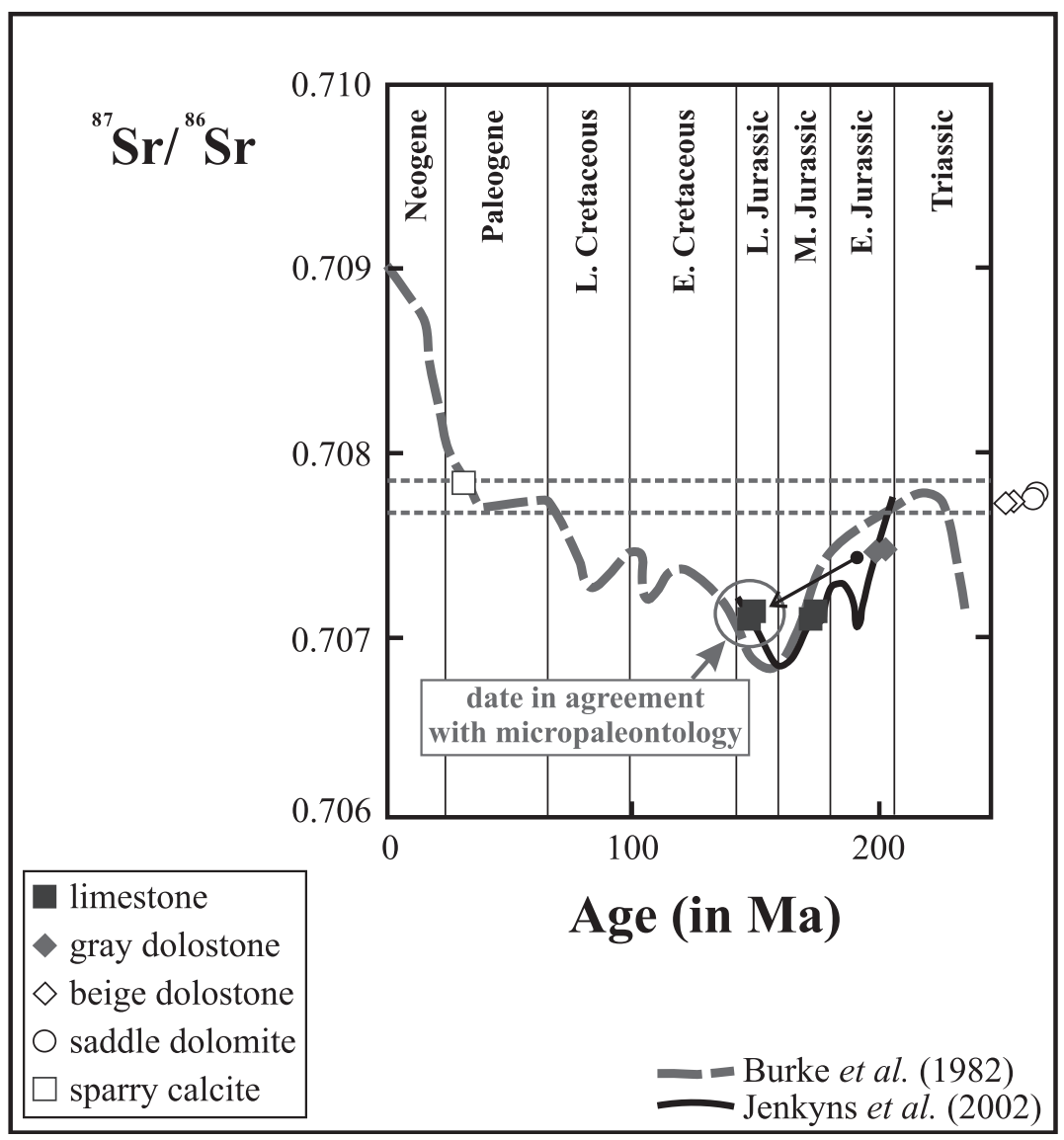

minimum precipitation temperatures of both beige and saddle dolomite range, according to $\mathrm{T}_{\mathrm{H}}$ measurements, between 50 and $90{ }^{\circ} \mathrm{C}$. Taking into account the burial curve (discussed above) and the natural regional geothermal gradient, the timing of the beige dolomitization can be constrained to the Late Jurassic-Early Cretaceous, when the maximum depth of burial did not exceed $1000 \mathrm{~m}$. Subsequently, these dolomites are defined as volcanism-associated hydrothermal dolomite (cf. Machel \& Lonnee, 2002). In addition, the beige dolostones were formed either through the replacement of the Kesrouane Formation limestones or the redolomitization of the grey stratabound dolostones. Thus, this second phase of dolomitization was accompanied by dolomite recrystallization, which may explain the resetting and homogenization of the $\delta^{18} \mathrm{O}$ signatures of the grey, beige and saddle dolomites.

Assuming that the Late Jurassic basalt formed in equilibrium with magmatic fluids, the latter would have similar ${ }^{87} \mathrm{Sr} /{ }^{86} \mathrm{Sr}$ composition ( $\approx$ 0.7030-0.7040; Abdel-Rahman, 2002). These values are much lower than the observed ones in the nearby beige and saddle dolomites. Barrett \&
Hardie (1986) have discussed Jurassic replacement dolostones (Smackover Formation) with Sr values of 0.7074-0.7078 compared with a Jurassic marine carbonate average value of $0 \cdot 7070$. They explained the radiogenic results by suggesting the flow of the dolomitizing fluids through terrigenous clastic sandstones. In the present case, the proximate sandstones to the Kesrouane Formation are the Late Jurassic-Early Cretaceous sandstones, which unconformably overlie the Jurassic rocks and are associated with volcanism and uplift. Another possible explanation for the high ${ }^{87} \mathrm{Sr} /{ }^{86} \mathrm{Sr}$ ratios of the discussed dolomites could result from fluids in equilibrium with the underlying Late Triassic evaporites (cf. Nadal, 2000).

\section{Dolomitization model}

The required kinetic and thermodynamic conditions for potential dolomitization need to be satisfied in order to propose a sound dolomitization model (Fig. 16). The restricted shallowmarine environments with associated significant evaporation, typical of the grey dolostones, may provide fluids with higher salinities and lower $\mathrm{Ca}^{2+} / \mathrm{Mg}^{2+}$ compared with sea water. These fluids 

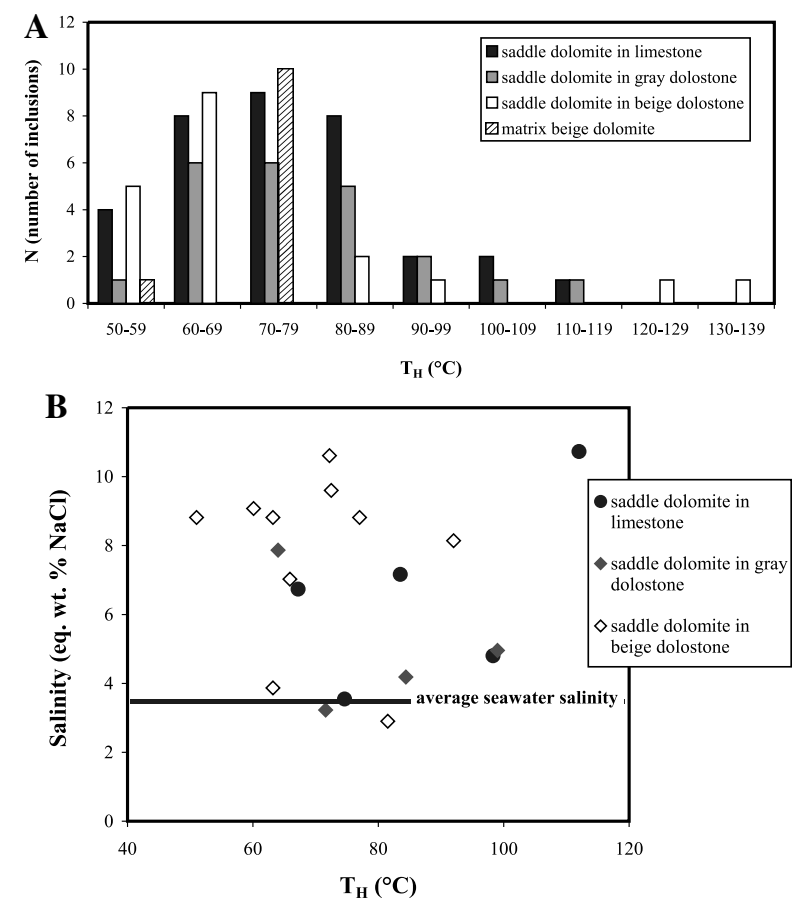

Fig. 14. (A) Distribution of temperature of homogenization values $\left(\mathrm{T}_{\mathrm{H}}\right.$; in $\left.{ }^{\circ} \mathrm{C}\right)$ for the saddle and beige rock matrix dolomites $(N=92)$. (B) $\mathrm{T}_{\mathrm{H}}$ vs. salinity (eq. wt $\%$ $\mathrm{NaCl}$ ) of saddle dolomites in grey and beige dolostones as well as in limestones. bear the kinetic and thermodynamic requirements for dolomitization (e.g. Machel \& Mountjoy, 1987). The palaeohydrogeological settings allow fluid circulation in the underlying shallowmarine carbonates. The matrix porosity of these grey dolostones (occluded with clays and oxides) does not allow high rates of water circulation, but rather leaching/percolating seepage. The geometric characteristics of the grey dolostones (i.e. broad, stratabound occurrences) also support a seepage reflux model (cf. Wilson et al., 1990).

Owing to the Late Jurassic volcanic activity (Laws \& Wilson, 1997), a local high geothermal gradient prevailed, subsequently elevating the temperatures of the ambient fluids. In addition, thermal doming and associated tectonic activity enhanced fracture permeability especially along regional extension faults and fractures. The temperature increase optimized the thermodynamic potential and facilitated the kinetic 'spike' for dolomitization and/or recrystallization of preexisting dolomites, a process that was further amplified by the increased permeability through fracture flow. In addition, the volcanic heat source may have initiated convective flow regimes subjecting the nearby rocks to the circulation of dolomitizing fluids, which were the result of

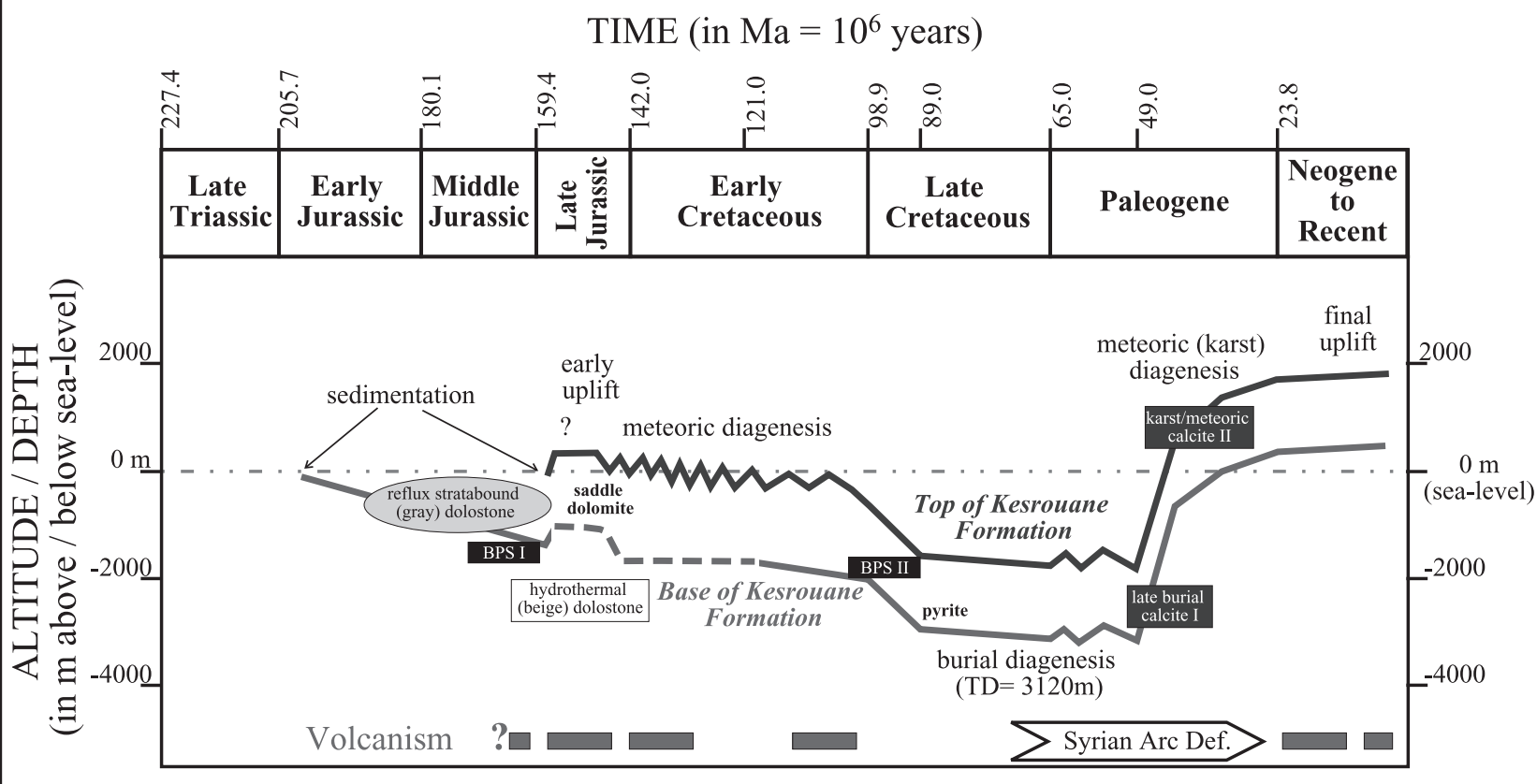

Fig. 15. Burial curves of the top and base of the Kesrouane Formation (Early-Late Jurassic) in northern Mount Lebanon. The volcanic activity is also reported. The burial depths were calculated from the known stratigraphy of central-northern Mount Lebanon (Jeita and Nahr Ibrahim; Dubertret, 1955; Renouard, 1955; Beydoun, 1977b). 


\section{TWO-STAGE DOLOMITIZATION MODEL: SEEPAGE REFLUX AND HYDROTHERMAL VOLCANISM-ASSOCIATED}

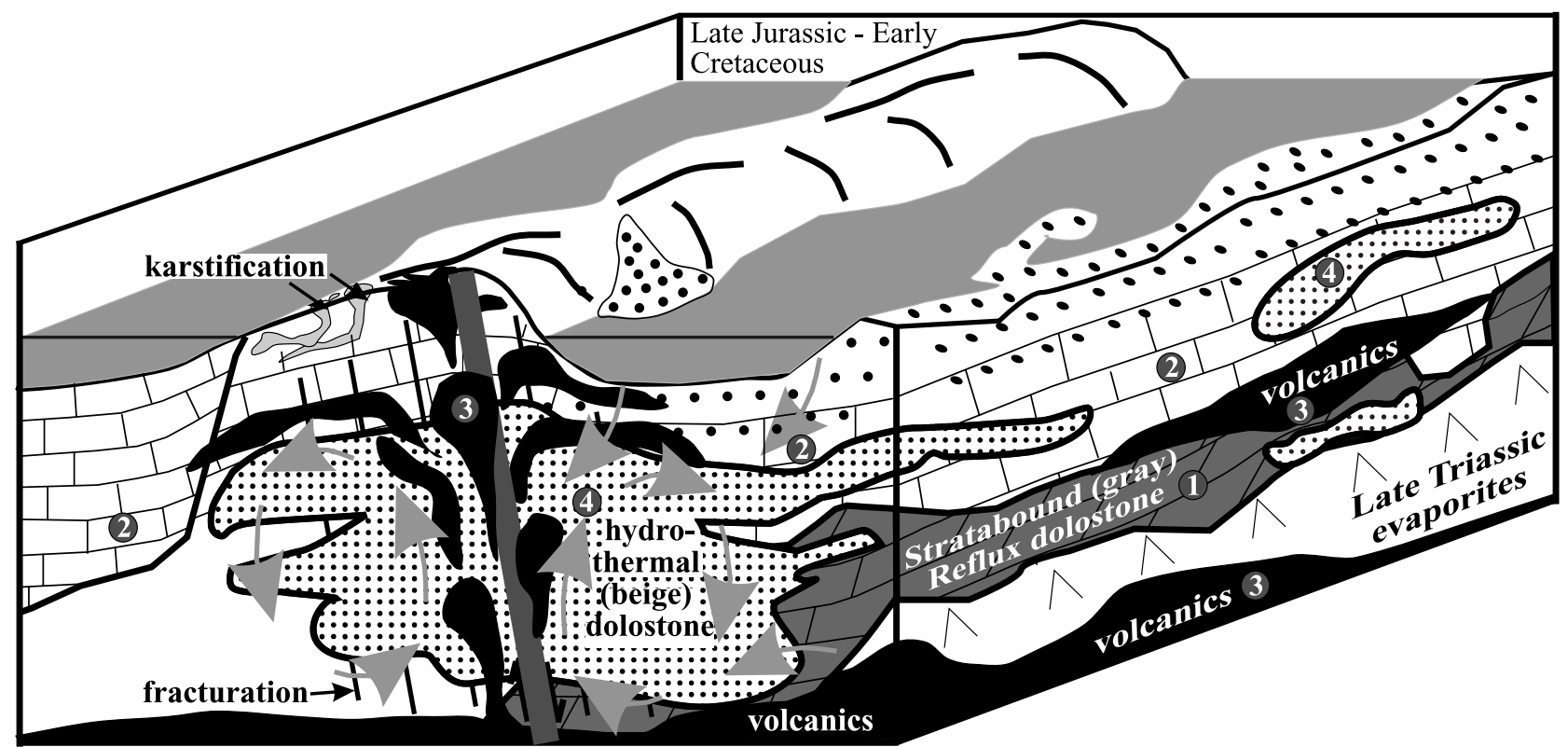

Fig. 16. Two-stage dolomitization model for the Kesrouane Formation (Early-Late Jurassic, Lebanon) showing the reflux (grey) stratabound Chouane dolostone and the hydrothermal (beige) volcanism-associated dolostone, as well as suggested fluid flow directions (arrows). The evolution trend is illustrated by label numbers. 1, grey dolostone formation; 2, sedimentation of the Nahr Ibrahim Member limestones; 3, volcanism and intense fracturing; 4, beige dolostone formation along faults.

mixing the underlying evaporative brines (dolomitizing fluids of the grey dolostones and/or the dissolution of Late Triassic evaporites) with the overlying sea water. This is well supported by the salinity results of the fluid inclusion analyses. Besides, such fluids were continuously replenished with $\mathrm{Mg}$, as they come from brines and sea water (e.g. Wilson et al., 1990). In such optimal conditions for dolomitization (with an open flow system and an immense source of dolomitizing fluids), the produced dolomites are more stoichiometric and ordered with lower clay contents (compared with the precursor limestone and dolostone). A decreasing Sr concentration trend with increasing stoichiometry from grey to beige dolostone also accounts for a chemical "purification' of the dolomites through successive recrystallization (cf. Land, 1980). Thus, the beige dolostones show a 'clean' coarse-crystalline texture with higher matrix porosity devoid of clays (compare Fig. 7 with Fig. 8). This process has the prospect of being repeated infinitely as long as its variables are maintained, resulting in dolomitization and subsequent recrystallization. Time, which is another controlling factor (cf. Hardie, 1987; Melim \& Scholle, 2002), may have spanned the Late Jurassic and Early Cretaceous. Finally, dolomitization stopped in the Cretaceous, when the hydrogeological configuration changed as the Jurassic aquifer became confined by the impervious Late Jurassic-Early Cretaceous strata, and volcanism ceased. Dolomite recrystallization after Early Cretaceous times is not favoured, as the measured $\mathrm{T}_{\mathrm{H}}$ values are below $90{ }^{\circ} \mathrm{C}$ while burial exceeded $2000 \mathrm{~m}$ - the regional geothermal gradient remained relatively high $55{ }^{\circ} \mathrm{C} \mathrm{km}^{-1}$ until the advent of the Syrian Arc deformations in the latest Cretaceous-Palaeogene (Ayalon \& Longstaffe, 1995).

\section{CONCLUSIONS}

Based on petrographic and geochemical investigations as well as field observation of Jurassic dolostones (Kesrouane Formation; central-northern Mount Lebanon), the following conclusions are drawn:

1 Two genetically distinct dolostones are recognized in the Jurassic strata of Lebanon and may occur throughout the eastern Mediterranean and Middle East regions in similar geological contexts, i.e. on the one hand, reflux stratabound 
dolostone (of Early Jurassic age) and, on the other hand, hydrothermal volcanism-associated dolostone (of Late Jurassic age).

2 Hydrothermal dolostones are more stoichiometric and ordered, characterized by lower contents of clays and iron oxides/hydroxides, compared with the reflux stratabound dolostones. They show a 'clean' (with corroded and leached non-carbonate fractions), more porous coarsecrystalline rock texture and evidence of recrystallization (neomorphism).

3 Kinetic and thermodynamic considerations support the dolomitization potential for the stratabound dolostone by traditional seepage reflux of evaporated sea water (hypersaline to mesosaline) into underlying shallow-marine limestones. Mixing of similar fluids - and/or waters originating from the dissolution of the underlying Late Triassic evaporites - and sea water (resulting in less saline fluids; $3 \cdot 5-12 \cdot 0$ eq. wt $\% \mathrm{NaCl}$ ), heated up by the Jurassic volcanism and circulated along faults and fractures caused the formation of hydrothermal dolostones. Enough time with stable palaeoenvironmental conditions was available for both reflux and hydrothermal dolomitization to occur.

4 Hydrothermal dolomitization ended before the Middle Cretaceous, when the Jurassic aquifer became confined by younger thick impervious layers. The maximum burial of the Kesrouane Formation $(\approx 3000 \mathrm{~m})$ occurred in the latest Cretaceous.

\section{ACKNOWLEDGEMENTS}

The authors are grateful to Dr R. Ottenburgs for his help with the X-ray diffraction measurements. Dr W. Heijlen is thanked for his considerable help with fluid inclusion measurements. Many fruitful discussions with Dr Ph. Muchez have improved this paper. Dr M. Joachimsky is thanked for performing the isotopic analyses. Dr D. Rehakova is also thanked for agreeing to study the micropalaeontology of some critical samples. $\mathrm{H}$. Nijs is acknowledged for technical assistance. A. Kelly and V. Gallagher performed Sr isotope measurements at SUERC. SUERC is supported by a consortium of Scottish universities. This work is partially sponsored by the Katholieke Universiteit Leuven (Afd. Fysico-chemische geologie). The first author (F. Nader) benefited from a research grant from the Lebanese National Council for Scientific Research. The International Association of Sedimentologists (IAS Postgraduate
Grant Scheme) sponsored part of the analyses. Critical reviews and valuable comments made by Dr E. Heydari and L. A. Melim have improved the presentation and content of this contribution and are greatly appreciated.

\section{REFERENCES}

Abdel-Rahman, A.-F.M. (2002) Mesozoic volcanism in the Middle East: geochemical, isotopic and petrographic evolution of extension-related alkali basalts from central Lebanon. Geol. Mag., 139, 621-640.

Adams, J.E. and Rhodes, M.L. (1960) Dolomitization by seepage reflux. AAPG Bull., 44, 1912-.

Adams, J.J., Rostron, B.J. and Mendoza, C.A. (2000) Evidence for two fluid mixing at Pine Point, NWT. J. Geochem. Explor., 69-70, 103-108.

Ayalon, A. and Longstaffe, F.J. (1995) Stable isotope evidence of the origin of diagenetic carbonate minerals from the Lower Jurassic Inmar Formation, southern Israel. Sedimentology, 42, 147-160.

Badiozamani, K. (1973) The dorag dolomitization model application to the Middle Ordovician of Wisconsin. J. Sed. Petrol., 43, 965-984.

Barrett, M.L. and Hardie, L.A. (1986) The development of permeability by void coalescence: Smackover dolomite of southern Alabama (abstract). AAPG Bull., 70, $562 \mathrm{pp.}$

Behrens, E.W. and Land, L.S. (1972) Subtidal Holocene dolomite, Baffin Bay, Texas. J. Sed. Petrol., 42, 155-161.

Benjamini, C., Druckman, Y. and Zak, I. (1993) Depositional cycles in the Ramon Group (Triassic), Makhtesh Ramon. Isr. J. Earth Sci., 41, 115-124.

Beydoun, Z.R. (1977a) Petroleum prospects of Lebanon: reevaluation. AAPG Bull., 61, 43-64.

Beydoun, Z.R. (1977b) The Levantine countries: the geology of Syria and Lebanon (maritime regions). In: The Ocean Basins and Margins, 4A, the Eastern Mediterranean (Eds A.E.M. Nairn, W.H. Kanes and F.G. Stehli), pp. 319-353. Plenum, New York.

Beydoun, Z.R. (1981) Some open questions relating to the petroleum prospects of Lebanon. J. Petrol. Geol., 3, 303-314.

Bodnar, R.J. (1993) Revised equation and table for determining the freezing point depression of $\mathrm{H}_{2} \mathrm{O}-\mathrm{NaCl}$ solutions. Geochim. Cosmochim. Acta, 57, 683-684.

Buchbinder, L.G. (1981) Dolomitization, porosity development and late mineralization in the Jurassic Zohar (Brur calcarenite) and Sederot Formations in Ashdod-Gan Yavne. Isr. J. Earth Sci., 30, 64-80.

Buchbinder, B. and Le Roux, J.P. (1993) Inner platform cycles in the Ardon Formation: Lower Jurassic, southern Israel. Isr. J. Earth Sci., 42, 1-16.

Buchbinder, L.G., Magaritz, M. and Goldberg, M. (1984) Stable isotope study of karstic-related dolomitization: Jurassic rocks from the coastal plain, Israel. J. Sed. Petrol., 54, 236-256.

Burke, W.H., Denison, R.E., Hetherington, E.A., Koepnick, R.B., Nelson, H.F. and Otto, J.B. (1982) Variations of seawater ${ }^{87} \mathrm{Sr} /{ }^{86} \mathrm{Sr}$ throughout Phanerozoic time. Geology, 10, 516-569.

Butler, G.P. (1969) Modern evaporative deposition and geochemistry of coexisting brines, the sabkha, Trucial Coast, Arabian Gulf. J. Sed. Petrol., 39, 70-89.

Carpenter, A.B. (1980) The chemistry of dolomite formation. I. The stability of dolomite. SEPM Spec. Publ., 28, 111-121. 
Crasquin-Soleau, S. and Barrier, E. (1998) Peri-Tethys Memoir 4: Epicratonic Basins of Peri-Tethyan Platforms. Mémoire. Muséum National d'Histoire Naturelle, Paris, 265 pp.

Crasquin-Soleau, S. and Barrier, E. (2000) Peri-Tethys Memoir 5: New Data on Peri-Tethyan Sedimentary Basins. Mémoire. Muséum National d'Histoire Naturelle, Paris, 266 pp.

Dercourt, J., Ricou, L.E. and Vrielynck, B. (1993) Atlas Tethys, Palaeoenvironmental Maps. Gauthier-Villars, Paris, 307 pp.

Dorobek, S.L., Smith, T.M. and Whitsitt, P.M. (1993) Microfabrics and geochemistry of meteorically altered dolomite in Devonian and Mississippian carbonated, Montana and Idaho. In: Carbonate Microfabrics (Eds R. Rezak and D.L. Lavoie), pp. 205-225. Springer-Verlag, New York.

Dubertret, L. (1955) Carte Géologique du Liban au 1/200000 avec Notice Explicative. République Libanaise, Ministère des Travaux Publiques, Beirut.

Folk, R.L. and Land, L.S. (1975) Mg/Ca ratio and salinity: two controls over crystallization of dolomite. AAPG Bull., 59, 60-68.

Goldberg, M. and Bogoch, R. (1978) Dolomitization and hydrothermal mineralization in the Brur Calcarenite (Jurassic), southern Coastal Plain, Israel. Isr. J. Earth Sci., 27, 36-41.

Goldsmith, J.R. and Graf, D.L. (1958) Relations between lattice constants and composition of Ca-Mg carbonates. Am. Mineral., 43, 84-101.

Hardie, L.A. (1987) Perspectives dolomitization: a critical view of some current views. J. Sed. Petrol., 57, 166-183.

Humphrey, J.D. (1988) Late Pleistocene mixing zone dolomitization, southeastern Barbados, West Indies. Sedimentology, 35, 327-348.

Jenkyns, H.C., Jones, C.E., Grocke, D.R., Hesselbo, S.P. and Parkinson, D.N. (2002) Chemostratigraphy of the Jurassic System: applications, limitations and implications for palaeooceanography. J. Geol. Soc. London, 159, 351-378.

Jones, B., Robert, L.W. and MacNeil, A.J. (2001) Powder X-ray diffraction analysis of homogeneous and heterogeneous sedimentary dolostones. J. Sed. Res., 71, 790-799.

Land, L.S. (1980) The isotopic and trace element geochemistry of dolomite: The state of the art. In: Concepts and Models of Dolomitization (Eds D.H. Zenger, J.B. Dunham and R.L. Ethington), SEPM Spec. Publ., 28, 87-110.

Laws, D.M. and Wilson, M. (1997) Tectonics and magmatism associated with Mesozoic passive continental margin development in the Middle East. J. Geol. Soc. London, 154, 757-760.

Lovelock, P.E.R. (1984) A review of the tectonics of the northern Middle East region. Geol. Mag., 121, 577-587.

Lumsden, D.N. (1979) Discrepancy between thin section and X-ray estimates of dolomite in limestone. J. Sed. Petrol., 49, 429-436.

Lumsden, D.N. and Chimahusky, J.S. (1980) Relationship between dolomite nonstoichiometry and carbonate facies parameters. SEPM Spec. Publ., 28, 123-137.

Machel, H.G. (1999) Effects of groundwater flow on mineral diagenesis, with emphasis on carbonate aquifers. Hydrogeol. J., 7, 94-107.

Machel, H.G. and Burton, E.A. (1994) Golden Grove dolomite, Barbados; origin from modified seawater. J. Sed. Res., A64, 741-751.

Machel, H.G. and Lonnee, J. (2002) Hydrothermal dolomite a product of poor definition and imagination. Sed. Geol., 152, 163-171.

Machel, H.G. and Mountjoy, E.W. (1987) General constraints on extensive pervasive dolomitization - and their application to the Devonian carbonates of western Canada. Bull. Can. Petrol. Geol., 35, 143-158.

Magaritz, M. (1975) Epigenetic dolomitization and mineralization in Jurassic rocks from Mount Hermon and northern Negev, Israel. Chem. Geol., 16, 295-306.

Mattes, B.W. and Mountjoy, E.W. (1980) Burial dolomitization of the Upper Devonian Miette buildup, Jasper National Park, Alberta. In: Concepts and Models of Dolomitization (Eds D.H. Zenger, J.B. Dunham and R.L. Ethington), SEPM Spec. Publ., 28, 259-297.

Melim, L.A. and Scholle, P.A. (2002) Dolomitization of the Capitan Formation forereef facies (Permian, west Texas and New Mexico): seepage reflux revisited. Sedimentology, 49, 1207-1227.

Mouty, M. (2000) The Jurassic in Syria: an overview. Lithostratigraphic and biostratigraphic correlations with adjacent areas. In: Peri-Tethys Mémoir 5. New Data on Peri-Tethyan Sedimentary Basins (Eds S. Crasquin-Soleau and E. Barrie), Mém. Mus. Natl Hist. Nat. Paris, 182, 159-168.

Mouty, M., Delaloye, D., Fontignie, D., Piskin, O. and Wagner, J.J. (1992) The volcanic activity in Syria and Lebanon between Jurassic and Actual. Schweiz. Mineral. Petrogr. Mitt., 72, 91-105.

Muchez, P. and Viaene, W. (1994) Dolomitization caused by water circulation near the mixing zone: an example from the Lower Viséan of the Campine Basin (northern Belgium). In: Dolomites - a Volume in Honour of Dolomieu (Eds B.H. Purser, M.E. Tucker and D.H. Zenger), SEPM Spec. Publ., 21, 155-166.

Nadal, J. (2000) Dolomías relacionadas con fallas durante la etapa de rift Jurásico superior-Cretácico inferior en la subcuenca de la Salzedella (Cuenca del Maestrazgo, Cadena Ibérica). Geotemas, 1, 247-252.

Nader, F.H. and Swennen, R. (2004) Petroleum prospects of Lebanon: some remarks from sedimentological and diagenetic studies of Jurassic carbonates. J. Mar. Petrol. Geol. (in press).

Nader, F.H., Swennen, R. and Ottenburgs, R. (2003) Karstmeteoric dedolomitization in Jurassic carbonates, Lebanon. Geol. Belg., 6, 3-23.

Nielsen, P., Swennen, R. and Keppens, E. (1994) Multiple-step recrystallization within massive ancient dolomite units: an example from the Dinantian of Belgium. Sedimentology, 41, 567-584.

Qing, H., Bosence, D.W. and Rose, E.P.F. (2001) Dolomitization by penesaline sea water in Early Jurassic peritidal platform carbonates, Gibraltar, western Mediterranean. Sedimentology, 48, 153-163.

Radke, B.M. and Mathis, R.L. (1980) On the formation and occurrence of saddle dolomite. J. Sed. Petrol., 50, 11401168.

Renouard, G. (1951) Sur la découverte du Jurassique inférieur (?) et du Jurassique Moyen au Liban. CR Acad. Sci., 232, 992-994.

Renouard, G. (1955) Oil prospects of Lebanon. AAPG Bull., 39, 2125-2169.

Renouard, G. (1967) Structural map of Qartaba horst and surrounding area. Unpubl. report, 6 pp, 12 plates.

Rosenbaum, J. and Sheppard, S.M. (1986) An isotopic study of siderites, dolomites and ankerites at high temperatures. Geochim. Cosmochim. Acta, 50, 1147-1150.

Saller, A.H. (1984) Petrologic and geochemical constraints on the origin of subsurface dolomite, Enewatak Atoll: an example of dolomitization by normal seawater. Geology, 12, 217-220. 
Searl, A. (1989) Saddle dolomite: a new view of its nature and origin. Mineral Mag., 53, 547-555.

Sibley, D.F. and Gregg, J.M. (1987) Classification of dolomite rock textures. J. Sed. Petrol., 57, 967-975.

Simms, M.A. (1984) Dolomitization by groundwater-flow systems in carbonate platforms. Trans. Gulf Coast Assoc. Geol. Soc., 34, 411-420.

Soussi, M. and M'Rabet, A. (1994) Burial dolomitization of organic-rich and organic-poor carbonates, Jurassic of central Tunisia. In: Dolomites - a Volume in Honour of Dolomieu (Eds B.H. Purser, M.E. Tucker and D.H. Zenger), SEPM Spec. Publ., 21, 429-455.

Sperber, C.M., Wilkinson, B.H. and Peacor, D.R. (1984) Rock composition, dolomite stoichiometry, and rock/water reactions in dolomitic carbonate rocks. J. Geol., 92, 609-622.

Stampfli, G.M., Mosar, J., Favre, P., Pillevuit, A. and Vannay, J.-C. (2001) Permo-Mesozoic evolution of the western Tethys realm: the Neo-Tethys East Mediterranean Basin connection. In: Peri-Tethys Memoir 6: Peri-Tethyan Rift/ Wrench Basins and Passive Margins (Eds P.A. Ziegler, W. Cavazza, A.H.F. Robertson and S. Crasquin-Soleau), Mém. Mus. Natl Hist. Nat. Paris, 86, 51-108.

Vahrenkamp, V.C. and Swart, P.K. (1990) New distribution coefficient for the incorporation of strontium into dolomite and its implications for the formation of ancient dolomites. Geology, 18, 387-391.

Vasconcelos, C. and McKenzie, J.A. (1997) Microbial mediation of modern dolomite precipitation and diagenesis under anoxic conditions (Lagoa Vermelha, Rio de Janeiro, Brazil). J. Sed. Res., 67, 378-391.

Wachter, E. and Hayes, J.M. (1985) Exchange of oxygen isotopes in carbon-dioxide-phosphoric acid systems. Chem. Geol., 52, 365-374.
Walley, C.D. (1998) Some outstanding issues in the geology of Lebanon and their importance in the tectonic evolution of the Levant region. Tectonophysics, 298, 37-62.

Walley, C.D. (2001) The Lebanon passive margin and the evolution of the Levantine Neothethys. In: Peri-Tethys Memoir 6: Peri-Tethyan Rift/Wrench Basins and Passive Margins (Eds P.A. Ziegler, W. Cavazza, A.H.F. Robertson and S. Crasquin-Soleau), Mém. Mus. Natl Hist. Nat. Paris, 86, 407-439.

Ward, W.C. and Halley, R.B. (1985) Dolomitization in a mixing zone of near-seawater composition, Late Pleistocene, northeastern Yucatan Peninsula. J. Sed. Petrol., 55, 407-420.

Wetzel, R. (1974) Etapes de la prospection pétrolière en Syrie et au Liban. Notes Mém. Comp. Franç. Pétrol. Paris, 11, 40-70.

Wilson, E.N., Hardie, L.A. and Phillips, O.M. (1990) Dolomitization front geometry, fluid flow patterns, and the origin of massive dolomite: the Triassic Latemar buildup, Northern Italy. Am. J. Sci., 290, 741-796.

Wood, B.G.M. (2001) Intraplate Primary and Subsidiary Basin Formation and Deformation - an Example from Central Syria. Unpubl. PhD Thesis, University of Oxford, Oxford, UK.

Wright, D.T. (1997) An organogenic origin for widespread dolomite in the Cambrian Eilean Dubh Formation, northwestern Scotland. J. Sed. Res., 67, 54-65.

Ziegler, P.A., Cavazza, W., Robertson, A.H.F. and CrasquinSoleau, S. (2001) Peri-Tethys Memoir 6: Peri-Tethyan Rift/ Wrench Basins and Passive Margins. Mém. Mus. Natl Hist. Nat. Paris, 186, 762 pp.

Manuscript received 27 March 2003; revision accepted 6 October 2003. 